\title{
Quantifying the effect of persistent dryer climates on forest productivity and implications for forest planning: a case study in northern Germany
}

\author{
Matthias Albert ${ }^{1 *}$ (D, Ralf-Volker Nagel ${ }^{1}$, Johannes Sutmöller ${ }^{2}$ and Matthias Schmidt ${ }^{1}$
}

\begin{abstract}
Background: Forest management decisions are based on expectations of future developments. For sound decisions it is essential to accurately predict the expected values in future developments and to account for their inherent uncertainty, for example the impact of climate change on forests. Changing climatic conditions affect forest productivity and alter the risk profile of forests and forest enterprises. Intensifying drought stress is seen as one major risk factor threatening forest management in the north German lowlands. Drought stress reduces tree growth and vitality and might even trigger mortality. But so far, it is not possible to quantify effects of a persistent dryer climate on forest productivity at a level suitable for forest management.
\end{abstract}

Methods: We apply a well-established single-tree forest growth simulator to quantify the effect of persistent dryer climates on future forest productivity. We analyse the growth of Scots pine (Pinus sylvestris L.), European beech (Fagus sylvatica L.) and oak (Quercus robur L. and Quercus petraea (Matt.) Liebl.) in two forest regions in the north German lowlands for a time interval of 60 years until 2070. The growth response under three different climate projections is compared to a baseline scenario.

Results: The results show clear differences in volume increment to persistent dryer climates between tree species. The findings exhibit regional differences and temporal trends. While mean annual increment at biological rotation age of Scots pine and oak predominantly benefits from the projected climate conditions until 2070, beech might suffer losses of up to $3 \mathrm{~m}^{3} \cdot \mathrm{ha}^{-1} \cdot \mathrm{yr}^{-1}$ depending on climate scenario and region. However, in the projection period 2051 to 2070 the uncertainty ranges comprise positive as well as negative climatic effects for all species.

Conclusions: The projected changes in forest growth serve as quantitative contributions to provide decision support in the evaluation of, for example, species future site suitability and timber supply assessments. The analysis of productivity changes under persistent dryer climate complements the drought vulnerability assessment which is applied in practical forestry in northwestern Germany today. The projected species' productivity has strong implications for forest management and the inherent uncertainty needs to be accounted for.

Keywords: Climate change, Forest growth, Forest productivity, Persistent dryer climate, Simulation study, Uncertainty

\footnotetext{
* Correspondence: matthias.albert@nw-fva.de

'Department of Forest Growth, Northwest German Forest Research Institute,

Göttingen, Germany

Full list of author information is available at the end of the article
} 


\section{Background}

A more and more aggravating climate change shakes one of the key features of forest planning, i.e. to assign species for cultivation according to site suitability (Brang et al. 2008). Formerly, species selection depended on static parameters, e.g. soil nutrients, site water budget and silviculture region as a substitute for regional climatic conditions. In the meantime, the rapidly changing climate affects the primary growing conditions well below a classical rotation period (e.g. Boisvenue and Running 2006; Pretzsch et al. 2014; Kohnle et al. 2014; Aertsen et al. 2014). Thus, forest planning has to account for dynamic site conditions and management decisions are based on expectations of future site developments. Besides projections of site conditions species selection for future forests depends on species resilience, its productivity and ecological conduciveness to name but a few. For sound decisions it is essential to accurately predict the expected values in future developments and to account for their inherent uncertainty, for example the impact of different climate change scenarios on forests.

Spittlehouse (2005) categorizes forest management actions to encounter climate change into societal adaptation, adaptation of the forest and adaptation to the forest. Societal adaptation covers adjusting people's expectations on forest services and changes in forest policy on management and conservation. Adaptation of the forest includes, for example, species selection. And adaptation to the forest comprises amongst others applying the adequate silvicultural regime, harvesting and utilization of more salvage wood and modifications in wood processing. All these measures can be proactive approaches to reduce vulnerability and enhance recovery in advance or reactive responses to diminish the impact afterwards (Ogden and Innes 2007).

According to Spittlehouse and Stewart (2003) determination of vulnerabilities and critical thresholds is an integral part of forest management adaptation to climate change. One of the core issues for forest management in the north German lowlands is the vulnerability of forests to projected changes in precipitation pattern. The most likely reduced rainfall in the growing season and increasing evapotranspiration due to rising temperatures will result in persistent dryer conditions or even drought stress on many forest sites. This will most likely affect forest productivity and alter the risk profile of forests and forest enterprises (Lindner et al. 2010, 2014).

As drought stress reduces tree growth and vitality and might even trigger tree mortality (Hanson and Weltzin 2000; Allen et al. 2010), adaptation measures should account for the effects of persistent dryer climate conditions on forests (Hogg and Bernier 2005). Two main future drought types can be distinguished. First, intense and more frequent dry spells in the growing season will occur in central Europe (IPCC 2013; Lindner et al. 2014). Second, the decrease of mean precipitation in the growing season along with increasing mean temperatures will result in long-term persistent dryer conditions. Many studies quantify growth reactions after short-term extreme drought events (e.g. Orwig and Abrams 1997; Klos et al. 2009; Michelot et al. 2012; Weber et al. 2013). These exemplary studies confirm the obviously negative effect of extreme drought events on tree growth while evincing differences according to for example species, sites, forest layers or distribution range. While these growth declines after singular short-term drought events are mostly reversible on many sites (Bigler et al. 2006; Zingg and Bürgi 2008; Sutmöller et al. 2017), still with increasing frequency of drought events the short-term growth reductions might aggregate to considerable losses in the long run.

Other case studies investigate the long-term effect of persistent dryer conditions on forest productivity. Kint et al. (2012) observed a drought-induced growth decline for beech in Belgium since the 1960s. Piovesan et al. (2008) related the reduction in stand basal area increment observed for beech forests in the central Appennines, Italy, since the last three to four decades to dryer conditions. Furthermore, they found evidence for a stronger effect of temperature increase to drought than reduction of precipitation. They conclude that for beech persistent drought stress will overcompensate the positive influence of an earlier beginning of the growing season. Barber et al. (2000) assume drought stress as one possible explanation for the lessening of the positive effect of temperature increase on radial growth of white spruce in interior Alaska. Based on observed radial growth data from Scots pine, European beech and Pedunculate oak in northern Germany Bauwe et al. (2015) developed regression models and projected growth until 2100 using the emission scenario A1B for future climate conditions. Their simulation results show growth reductions for beech and oak with increasingly dryer conditions while Scots pine did not display a clear trend.

These case studies give evidence for long-term growth trends which correspond to persistent drought stress. But so far, it is not possible to satisfactorily quantify effects of persistent dryer climates on a level suitable for forest management (e.g. Adams et al. 2009; Choat et al. 2012; Anderegg et al. 2013). Until now, in Germany forest planning relies on drought vulnerability thresholds which are based on expert knowledge and/or singular observations on monitoring plots or experimental sites or current presence/absence observations in relation to various environmental factors (e.g. Spellmann et al. 2011, 2015; Kölling et al. 2009; Falk et al. 2013; Hanewinkel et al. 2014). To enhance the understanding of 
interactions between persistent dryer climates and forest productivity and to harness quantitative drought assessment information for forest planning we pursue three goals in the presented research: (1) We quantify the effect of persistent dryer climates on forest productivity in two north German forest regions until 2070. This is pivotal as we want to complement the currently qualitative drought vulnerability assessment by quantitative effects of climate change on forest growth. For this purpose we apply a single-tree growth simulator which already serves as a prediction tool for practical forest planning in northern Germany. For our analysis we present and employ an extended site-sensitive model version. (2) We quantify the uncertainty inherent in climate change by applying three different climate projections. (3) Finally, we point out how forest growth simulations of actual current forests in a specified region and for a defined projection period might add information to support forest planning decisions. This analysis serves as a first step towards a quantitative drought vulnerability assessment to be considered in forest management on a regional basis, for example for silvicultural management strategies, species selection decisions or long-term timber supply studies.

\section{Methods}

This study is based on projections of forest development applying the site-sensitive version of the single-tree growth simulator WaldPlaner 2.1 (Hansen and Nagel 2014). Site-sensitivity comprises, among others, effects of climatic conditions on tree growth, i.e. the impact of precipitation and temperature. In the simulation design we vary the climatic conditions according to three climate scenarios while all other factors are held constant. Thereby, differences in forest growth in the simulation results are traced back solely to variations in climate.

\section{Study area}

In this study we use forest inventory data from two regions Uelzen and Fläming in the north German lowlands (Fig. 1).

The two regions feature different current climatic and site conditions with favourable water supply in Uelzen and already today problematic precipitation and available water capacity in the lower parts of the Fläming region at least for less tolerant tree species (Table 1 ). Climate change is believed to increase water shortage in the future. Standard forest management surveys (cf. Böckmann et al. 1998) provide information on forest stands at 999 locations in Uelzen and 1008 locations in Fläming.

\section{Model description}

Figure 2 displays the individual components of the WaldPlaner 2.1 simulation framework to project forest development (for equations and parameters refer to Hansen and Nagel 2014). Single growth functions and a previous version of the model system have been extensively validated (Schmidt and Hansen 2007; Vospernik et al. 2010, 2015; Nagel 2013; Sprauer and Nagel 2015). One growth projection step commonly covers a 5 -year period. The single tree data base stores individual tree parameters as described in the initialization data section below. An ingrowth routine adds trees to the data set and the density-dependent mortality model predicts single tree mortality. The competition

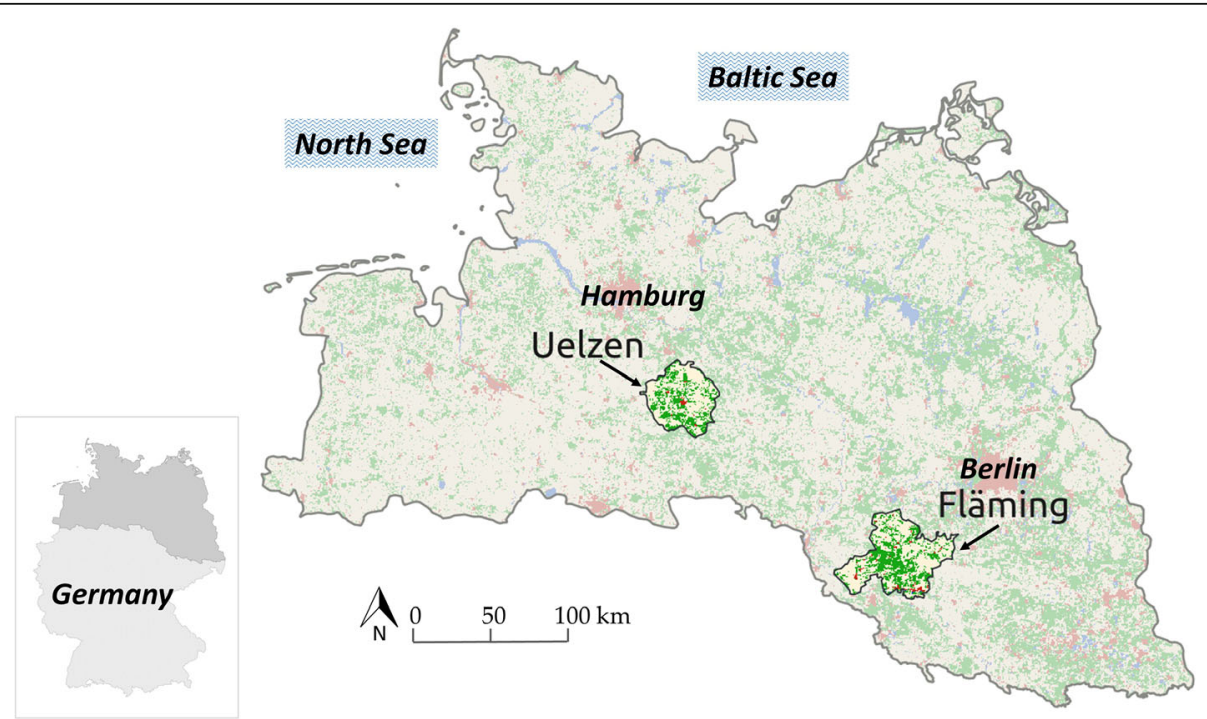

Fig. 1 The two study regions Uelzen and Fläming in the north German lowlands near the cities of Hamburg and Berlin (land cover data in the overview map @ ESA / ESA GlobCorine Project, led by Université Catholique de Louvain) 
Table 1 Characteristics of Uelzen and Fläming (climate values as averages in the period 1991 to 2010; cwb gs: climatic water balance (=precipitation-evapotranspiration for grass) in growing season; awc: available water capacity)

\begin{tabular}{|c|c|c|c|c|c|c|c|}
\hline & \multicolumn{3}{|c|}{ Species area proportion (\%) } & \multirow{2}{*}{$\begin{array}{l}\text { Annual } \\
\text { mean } \\
\text { temp. } \\
\left({ }^{\circ} \mathrm{C}\right)\end{array}$} & \multirow{2}{*}{$\begin{array}{l}\text { Annual } \\
\text { prec. } \\
\text { (mm) }\end{array}$} & \multirow{2}{*}{$\begin{array}{l}\mathrm{cwb}_{\mathrm{gs}} \\
(\mathrm{mm})\end{array}$} & \multirow{2}{*}{$\begin{array}{l}\text { Mean } \\
\text { awc } \\
(\mathrm{mm})\end{array}$} \\
\hline & pine & beech & oak & & & & \\
\hline Uelzen & 61.3 & 4.8 & 6.1 & 9.2 & 727 & -65 & 110 \\
\hline Fläming & 73.5 & 12.8 & 5.9 & 9.8 & 572 & -216 & 123 \\
\hline
\end{tabular}

index (c66) and the change in the competition index (c66c) due to tree removal and mortality are calculated afterwards. Basal area increment (bai) is a function of the tree parameters age, crown surface area (csa), the competition index and its change. The updated diameter at breast height (dbh) is then used to derive an updated tree height applying the site-sensitive longitudinal height-diameter model by Schmidt (2010) which utilizes climate and soil data. When applying climate scenarios in impact studies it is recommended to use average values of 30 -year periods (IPCC 2013, p. 1450). Therefore, for each 5-year growth prediction the values of mean annual temperature sum in the growing season and aridity index are calculated for a 30-year period centered around the respective projection period and applied to the height-diameter model. Furthermore, development of crown surface area (csa) depends on crown width and crown length which, in turn, are functions of tree diameter and tree height. Thus, as tree height development is predicted site-sensitively soil and climate parameters also affect diameter increment. Finally, thinning and harvesting rules can be applied.

The height-diameter model by Schmidt (2010) constitutes the site-sensitive core of the single-tree growth model. It builds on a height-diameter model by Lappi (1997) which is a modified version of the Korf function (Eq. 1).

$$
\ln \left(H_{k t i}\right)=A-B x_{k t i}+\epsilon_{k t i}
$$

with

$$
x_{k t i}=\frac{\left(d b h_{k t i}+\lambda\right)^{-C}-(30+\lambda)^{-C}}{(10+\lambda)^{-C}-(30+\lambda)^{-C}}
$$

and

$H_{\text {ktti }}$ : tree height value [m] for tree $i$ in stand $k$ at time $t$ with $\varepsilon_{k t i} \sim N\left(0, \sigma^{2}\right)$;

$d b h_{k t i}: \mathrm{dbh}$ of tree $i[\mathrm{~cm}]$ in stand $k$ at time $t$;

$A, B, C, \lambda$ : parameters of the height-diameter model.

The parameter values of $C$ and $\lambda$ in Eq. 1.1 are optimized to yield minimum quadratic deviation of the model. Further on, these values are fixed and Lappi's model becomes linear. As convenient properties Lappi's

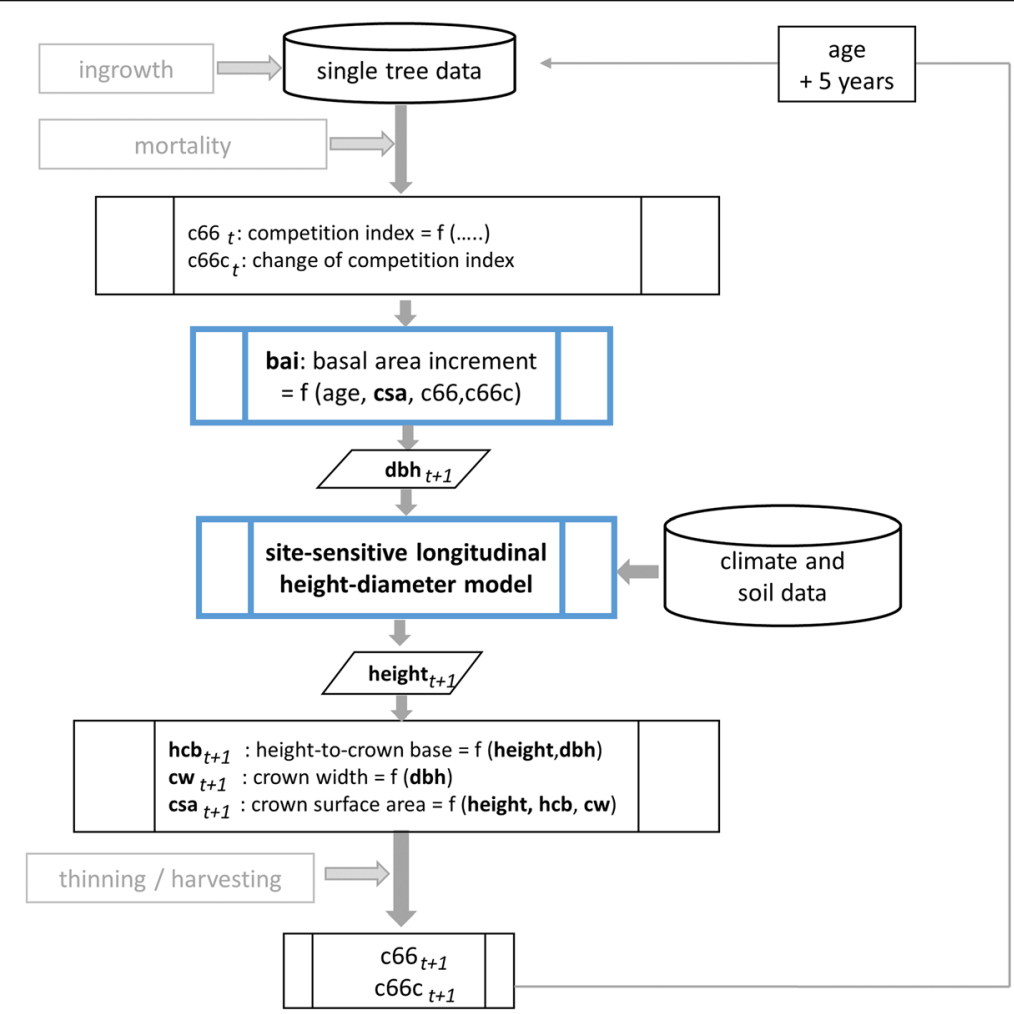

Fig. 2 Flowchart of the WaldPlaner 2.1 simulation framework (directly or indirectly site-sensitive model components and variables in bold) 
model formulation is biologically interpretable with $A$ being the level and $B$ the slope of the height-diameter curve on logarithmic scale and the two parameters show low collinearity.

The longitudinal height-diameter model (Eq. 2) by Schmidt (2010) is formulated as a generalized additive model.

$$
\begin{aligned}
\ln \left\{E\left(H_{k t i}\right)\right\} & =\widehat{p_{1 a}}+p_{2 a}\left(1-\widehat{e}^{-\widehat{p_{3 a} a g e_{k t i}}}\right)^{\widehat{p_{4 a}}}+f_{2 a}\left(r d_{k t i}\right) \\
& +f_{3 a}\left(y g_{k i}\right)+f_{4 a}\left(t_{s u m_{k}}\right)+f_{5 a}\left(\operatorname{ari}_{k}\right) \\
& +f_{6 a}\left(\text { lon }_{k}, \text { lat }_{k}\right)-p_{0 b} x_{k t i}-p_{1 b} a g e_{k t i} x_{k t i}-p_{2 b} \text { elev }_{k} x_{k t i}
\end{aligned}
$$

with

$E\left(H_{k t i}\right)$ : expected value of tree height $[\mathrm{m}]$ for tree $i$ in stand $k$ at time $t$ with $H_{k t i} \sim N\left(\exp \left(\eta_{k t i}\right), \sigma^{2}\right)$;

age $_{k t i}$ : age [years] of tree $i$ in stand $k$ at time $t$;

$r d_{k t i}:$ relative diameter $[\mathrm{cm}]$ as the ratio of $\mathrm{dbh}$ of tree $i$ in stand $k$ at time $t$ and the respective quadratic mean diameter;

$y g_{k i}$ : year of germination of tree $i$ in stand $k$;

tsum $_{k}$ : average temperature sum in the growing season

$\left[{ }^{\circ} \mathrm{C}\right]$ in stand $k$ in the climatic reference period 1961 to 1990;

ari $_{k}$ : average aridity index value by De Martonne (1926) in stand $k$ in the climatic reference period 1961 to 1990 ;

lon $_{k}$, lat $t_{k}$ : Gauss-Krueger coordinates of stand k's centroid;

ele $_{k}$ : elevation $[\mathrm{m}]$ above sea level of stand k's centroid;

$\widehat{p_{x a}}$ : parameter constants (with $x=1,3$ and 4, respectively) of Chapman-Richards function used to approximate the age trend of the original parameter $\mathrm{A}$ (see formula 1);

$p_{2 a}$ : parameter of Chapman-Richards function used to approximate the age trend of the original parameter $\mathrm{A}$ (see formula 1);

$f_{x a}$ : one-dimensional smoothing regression term (with $x=2,3,4$ and 5 , respectively) to describe non-linear effects of independent variables on the original parameter A (see formula 1);

$f_{6 a}$ : two-dimensional smoothing regression spline to account for large scale spatial autocorrelation of the original parameter A (see formula 1);

$p_{x b}$ : parameter of linear effects (with $x=0,1$ and 2, respectively) on the original parameter B (see formula 1).

In a first step the expected tree height value is estimated using, among others, the climate variables temperature sum in the growing season (tsum) and De Martonne's (1926) aridity index (ari) as described in the climate data section below. The model is parameterized based on data of the first two German National Forest Inventories, the forest enterprise inventory of Lower Saxony and experimental plots for Pedunculate and Sessile oak, European beech, Norway spruce, Douglas-fir and Scots pine in Germany (Eq. 2).

The second stage of the height-diameter model (Eq. 3) uses the predictors available water capacity $(a w c)$, soil nutrients (nut) and ground water class $(g w)$ to further enhance site sensitivity (cf. Fleck et al. 2015, p. 47). A separate second stage is necessary as the soil parameters were not available throughout Germany during model development but only for Lower Saxony.

$$
\begin{aligned}
\ln \left\{E\left(H_{k t i}\right)\right\}= & \ln \left\{E\left(\widehat{\left.H_{k t i}\right)}\right\}+f_{1 a}\left(a w c_{k}\right) Z_{k}\right. \\
& +g w_{k}^{T} \beta_{1}+n u t_{k}^{T} \beta_{2} \\
& +f_{2 a}\left(\text { lon }_{k}, \text { lat }_{k}\right)
\end{aligned}
$$

with

$E\left(H_{k t i}\right)$ : expected tree height value $[\mathrm{m}]$ for tree $i$ in stand $k$ at time $t$ with $H_{k t i} \sim N\left(\exp \left(\eta_{k t i}\right), \sigma^{2}\right)$;

$\widehat{E\left(H_{k t i}\right)}$ : estimated expected tree height value $[\mathrm{m}]$ for tree $i$ in stand $k$ at time $t$ using Eq. 2;

$a w c_{k}$ : available water capacity in stand $k[\mathrm{~mm}]$;

$Z_{k}$ : indicator variable to define ground water impact in stand $k$ with categories "ground water impact" and "no ground water impact";

$g w_{k}$ : vector of the categorical variable to define ground water impact with categories "no ground water impact (ground water table $>2.5 \mathrm{~m}$ )", "low to medium ground water impact (ground water table 0.95 to $2.5 \mathrm{~m}$ )" and "medium to strong ground water impact (ground water table $<0.95 \mathrm{~m}$ )";

nut $_{k}$ : vector of the categorical variable to define soil nutrient supply in stand $k(1=$ very poor, $2=$ poor, $3=$ medium, 4 = good, 5 = rich; including further differentiation using + and - variants);

$\operatorname{lon}_{k}$, lat $k_{k}$ : Gauss-Krueger coordinates of stand k's centroid;

$f_{1 a}$ : one-dimensional smoothing regression spline to describe the non-linear effect of awc;

$f_{2 a}$ : two-dimensional smoothing regression spline to account for large scale spatial autocorrelation;

$\beta_{1}, \beta_{2}$ : coefficient vectors.

The estimated expected tree height values calculated with Eq. 2 are used as an offset in the second model stage (Eq. 3).

Both stages of the site-sensitive height-diameter model are implemented in the forest simulation framework WaldPlaner. Various studies already proved the climate-sensitivity and biological plausibility of the model (Schmidt 2010; Albert et al. 2015, 2016; Fleck et al. 2015). In a comparative analysis bias and precision of the model proved satisfying (Albrecht et al. 2017). 


\section{Soil data}

The height-diameter model requires among others soil data as predictors. For each of the 2007 locations in Uelzen and Fläming information on soil nutrients, available water capacity and a classification of groundwater availability is provided. Details are given in Albert et al. (2015, 2016). In this analysis, however, soil data is of lower interest as the comparison of tree growth focusses on the climate aspect. Nevertheless, due to the interaction between climate and soil parameters the effect of soil properties may differ among the simulation runs.

\section{Climate data}

The $5^{\text {th }}$ IPCC report introduces a new generation of climate scenarios to depict the future concentration of global warming gases in the atmosphere (IPCC 2013). Four scenarios, denominated representative concentration pathways (RCP), are selected in the report. The scenarios differ in the underlying pathways, i.e. under RCP 8.5 rising $\mathrm{CO}_{2}$-equivalents after 2100 (>1,370 ppm in 2100), two pathways stabilizing the $\mathrm{CO}_{2}$-equivalents on different levels in 2100 ( $\sim 850$ ppm under RCP 6.0 and $\sim 650 \mathrm{ppm}$ under RCP 4.5), and a peak and decline pathway with a maximum of $\sim 490$ ppm before 2100 under RCP 2.6.

Based on the climate scenario RCP 8.5 (Moss et al. 2010; van Vuuren et al. 2011) three climate projections from 2011 to 2070 specify the range of potential climate change in this study. The three projections are calculated using the global circulation models INM-CM4 (Volodin et al. 2010), ECHAM6 (Stevens et al. 2013) and ACCESS1.0 (Bi et al. 2013).

The regional climate model STARS (Orlowsky et al. 2008) further downscales the realisations of the global circulation models to Germany. In the period 2051 to 2070 the projected temperature based on INM-CM4 shows a $1.1^{\circ} \mathrm{C}$ deviation from today's (1991 to 2010) mean annual temperature for the north German lowlands. ECHAM6 exhibits a $1.6^{\circ} \mathrm{C}$ deviation and $A C$ CESS1.0 $2.7^{\circ} \mathrm{C}$. Subsequently, these three climate scenarios are labelled minimum, median and maximum climate run. Furthermore, a retrospective climate scenario from 1951 to 2010 is projected using STARS based on daily weather records from 1218 climate stations run by the German Weather Service. Thus, a consistent time series from 1951 to 2070 is provided for each climate station.

The site-sensitive height-diameter model applies the climate parameters temperature sum in the growing season and aridity index as predictors. The beginning of the growing season is defined using the model LNVAR by Menzel (1997, p. $52 \mathrm{ff}$ ). The end is calculated according to suggestions by Walther and Linderholm (2006) and Frich et al. (2002) using either the temperature criterion or the short day criterion, whichever is met first. The temperature criterion applies, if the moving average of mean temperature in a 7-day period between July and October falls below $5^{\circ} \mathrm{C}$. We follow von Wilpert (1990) and fix the short day criterion, defined as the day length needed for xylem growth, to October 5. De Martonne (1926) defines the aridity index as the ratio of annual precipitation sum [mm] and mean annual temperature $\left[{ }^{\circ} \mathrm{C}\right]+10$. We calculate the aridity index based on annual values as the soil functions as a water storage. Finally, the temperature sum in the growing season and the aridity index is provided for all 2007 locations in Uelzen and Fläming in yearly resolution from 1951 to 2070 by interpolating the projected values of all climate stations within a 20 $\mathrm{km}$ distance from the respective location. The interpolation is done using WaSiM-ETH's (Schulla 2015; Schulla and Jasper 2007) distance-weighted regression model.

Figure 3 illustrates how the temperature sum in the growing season and aridity index develop differently in Uelzen and Fläming over time. The linear trend lines clearly display an increase in temperature over time (Fig. 3a and b). For the aridity index, with lower values indicating dryer conditions, the findings show increasing dryer conditions with time (Fig. 3c and d). The temperature trend in Uelzen is on a slightly lower level than in Fläming. However, the aridity index states much dryer conditions in Fläming.

The baseline climate scenario is used as a reference in this study. It requires to avoid any temporal changes in temperature sum and aridity index looking at 20-year averages. Annual fluctuations, however, are necessary to display short-term climate variability. Therefore, the annual climate values of the reference period 1991 to 2010 are randomly mixed to create new sequences for each of the three projection periods 2011 to 2030, 2031 to 2050, and 2051 to 2070. This procedure returns identical means and variances for the three future periods.

\section{Initialization data}

Using the forest simulation framework WaldPlaner 2.1 (Hansen and Nagel 2014) 2007 forest stands with individual trees are generated based on the provided stand information, i.e. for every species and for each layer values on age, quadratic mean diameter, and volume per hectare as well as species proportions and stocking degree. Single tree heights are estimated site-sensitively applying the height-diameter model. These initial tree heights are further updated in each 5-year prediction period with newly predicted values from the heightdiameter model. As the survey data has different inventory dates all stands are projected to 2010 as a uniform starting year for the growth projections. 


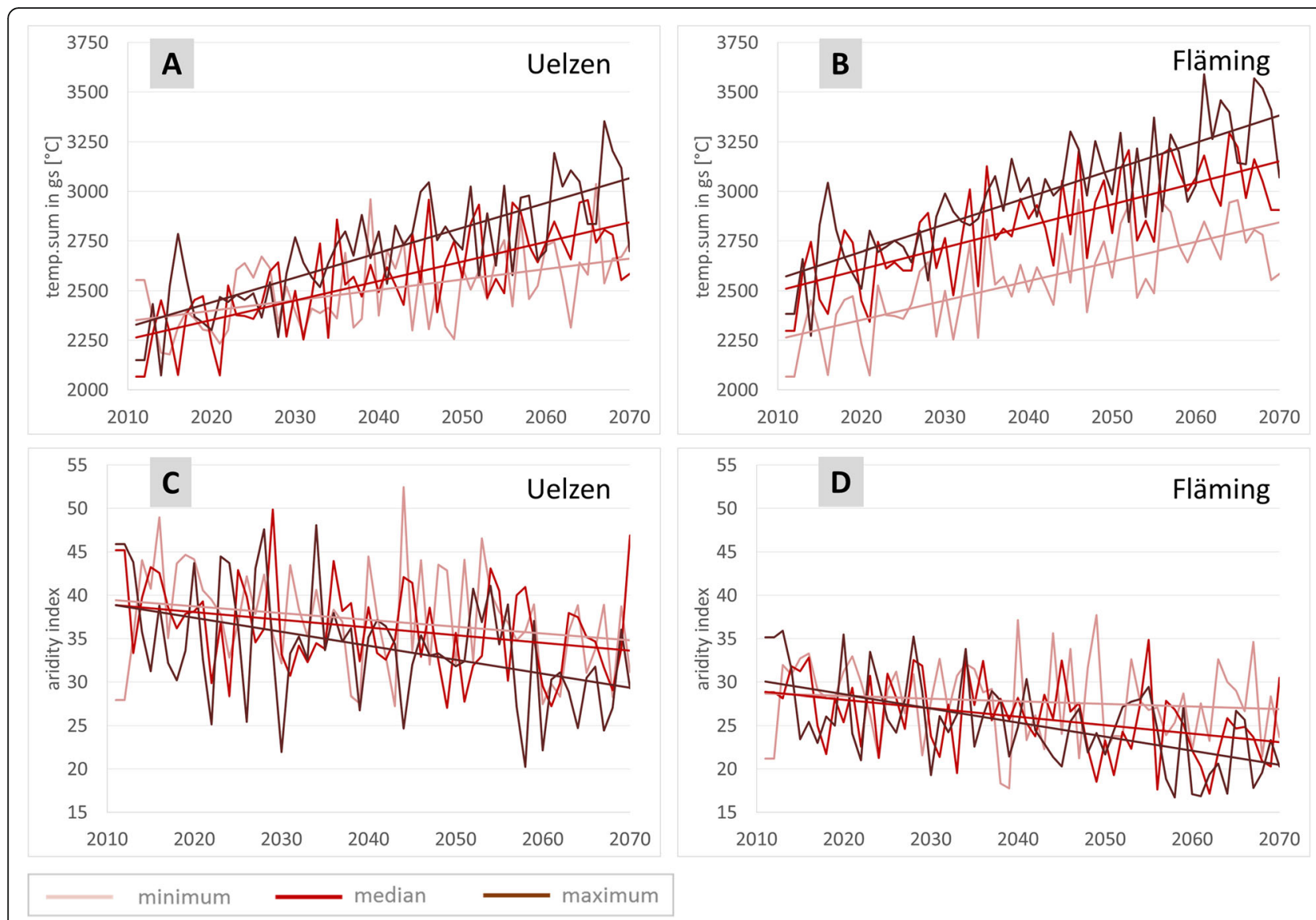

Fig. 3 Climate parameters over time for the simulation period 2011 to 2070 projected with STARS using RCP 8.5 (a average temperature sum in the growing season in Uelzen under the minimum, median and maximum climate run, $\mathbf{b}$ corresponding figure for Fläming, $\mathbf{c}$ average aridity index value in Uelzen under the minimum, median and maximum climate run, $\mathbf{d}$ corresponding figure for Fläming)

The effect of different climatic conditions on singletree volume increment, periodic volume increment at stand level and mean annual increment at biological rotation age of the three most abundant tree species in Uelzen and Fläming, i.e. Scots pine (Pinus sylvestris L.), European beech (Fagus sylvatica L.) and Pedunculate and Sessile oak (Quercus robur L. and Quercus petraea (Matt.) Liebl.), is analysed comparing the simulation results under three different climate projections to a baseline scenario with constant climate until 2070. For the analysis we distinguish three 20 -year projection periods, i.e. the first period from 2011 to 2030, the second from 2031 to 2050 and the third from 2051 to 2070. In the course of the simulations more and more individual trees are removed by the thinning and harvesting algorithm or due to mortality and new trees are introduced by the ingrowth algorithm. Ingrowth, on the other hand, is not identical on a single tree basis among the four simulation runs. Thus, although starting with quite a number of individuals in 2011 in later periods the data base for tree-wise comparison becomes too small especially in younger age classes. Therefore, tree collectives are selected for comparison (cf. Additional file 1: Tables S1 and S2). Under each scenario all trees of one species, i.e. pine, beech or oak, being alive at the end of the respective 20-year projection period or being cut or dying because of density induced mortality during the period form one collective. As a result 9 collectives under the baseline scenario (3 periods $\times 3$ species) are compared to 27 collectives under climate change ( 3 periods $\times 3$ species $\times 3$ climate scenarios). For each tree within the collectives the mean annual volume increment is predicted.

The collectives to be compared, i.e. per species and within one period, consist of roughly the same number of individuals, most of them being identical, and have a very similar age span. The tree dimensions vary as projected tree growth depends on the assumed climate conditions. The establishment of new stands and possible species conversions, influence the age structure of all collectives as well. Under each simulation run the same settings for the business-as-usual silvicultural treatment scenario and the same rule-sets for regeneration and forest conversion apply (cf. Albert et al. 2015). 


\section{Deriving the climatic effect on volume increment}

Based on the tree collectives described above the climate effect on mean single tree volume increment $\left[\mathrm{m}^{3} \cdot \mathrm{yr}^{-1}\right]$ over initial volume classes is calculated separately for tree species and projection period as the deviation between the respective climate scenario and the baseline scenario:

$$
\Delta \bar{i} \bar{v}_{j x}=\frac{\sum_{i=1}^{n_{j x}} i v_{i_{j_{x}}}}{n_{j_{x}}}-\frac{\sum_{i=1}^{n_{j_{b}}} i v_{i j_{b}}}{n_{j_{b}}}
$$

with

$i v_{i j x}, i v_{i j b}$ : volume increment of tree $i$ in initial volume class $j$ under climate scenario $x$ and under baseline $b$ $\left[\mathrm{m}^{3} \cdot \mathrm{yr}^{-1}\right]$;

$x$ : climate scenario (minimum, median, maximum);

$n_{j x}, n_{j b}$ : number of trees in initial volume class $j$ under climate scenario $x$ and under baseline $b$.

Periodic volume increment is also calculated based on the tree collectives, however, only trees of the dominant stand are taken into account as it is common in forest planning to differentiate between layers. The deviation in periodic volume increment $\left[\mathrm{m}^{3} \cdot \mathrm{ha}^{-1} \cdot \mathrm{yr}^{-1}\right]$ between the respective climate scenario and the baseline scenario is derived separately for each of the three species and for each of the three projection periods as follows:

$\Delta i \bar{V}_{x}=\frac{\sum_{j=1}^{m_{x}}\left[\left(\sum_{i=1}^{n_{j j_{x}}} i v_{i_{x}}\right) / b a_{j_{x}}\right]}{m_{x}}-\frac{\sum_{j=1}^{m_{b}}\left[\left(\sum_{i=1}^{n_{k_{b}}} i v_{i i_{b}}\right) / b a_{j_{b}}\right]}{m_{b}}$

with

$i v_{i j x}, i v_{i j b}$ : volume increment of tree $i$ in stand $j$ under climate scenario $x$ and under baseline $b\left[\mathrm{~m}^{3} \cdot \mathrm{yr}^{-1}\right]$;

$b a_{j x}, b a_{j b}$ : proportion of respective species basal area in stand $j$ under climate scenario $x$ and under baseline $b$; $x$ : climate scenario (minimum, median, maximum);

$n_{k j x}, n_{k j b}$ : number of trees of species $k$ in stand $j$ under climate scenario $x$ and under baseline $b$;

$m_{x}, m_{b}$ : number of stands under climate scenario $x$ and under baseline $b$.

The climate effect on mean annual increment at biological rotation age $\left(M A I_{\text {max }}\right)$ is derived only for stands which are or soon will be close to rotation age, i.e. European beech and Scots pine stands aged 81 and older and oak stands aged 121 and older at the end of the respective projection period. The rationale of this restriction is that we derive $M A I_{\max }$ based on the simulated stand's top height using static site index assessment refraining from the dynamic influence of changing site conditions which is a permissible approximation in this case. In order to obtain $M A I_{\text {max }}$-values for younger stands taking climate change into consideration we would need to project forest growth climate-sensitively for younger stands beyond 2070. However, for this study no data on climate projections beyond 2070 is available. Therefore, only stands close to rotation age warrant a meaningful interpretation of $M A I_{\text {max }}$-values under climate change conditions.

The site index at age 100 (SI) is estimated using the yield tables by Nagel (2017) based on the simulated top height and age of beech, oak and pine occurrence in each stand $i$ at the end of the respective projection period. The SI-values are further transformed into MAI$\max$-values applying following functions:

$$
\text { European beech : } \begin{aligned}
M A I_{\max _{i}} & =0.0139 \times S I_{i}^{2}-0.187 \\
& \times S I_{i}+1.5186
\end{aligned}
$$

$$
\begin{aligned}
& \text { Sessile and pedunculate oak : MAI } \max _{i} \\
& \begin{aligned}
&=0.0046 \times S I_{i}^{2}+0.1855 \times S I_{i} \\
& \text { Scots pine : } M A I_{\text {max }_{i}}= 0.003 \times S I_{i}^{2}+0.3702 \\
& \times S I_{i}-2.6784
\end{aligned}
\end{aligned}
$$

Finally, the climate effect on $M A I_{\max }\left[\mathrm{m}^{3} \cdot \mathrm{ha}^{-1} \cdot \mathrm{yr}^{-1}\right]$ is calculated separately for tree species and projection period as follows:

$$
\Delta \overline{M A I} \max _{x}=\frac{\sum_{i=1}^{n} M A I_{\max _{i_{x}}}}{m_{x}}-\frac{\sum_{i=1}^{m} M A I_{\max _{i_{b}}}}{m_{b}}
$$

with

$M A I_{\max _{i x}}, M A I_{\max _{i b}}$ : mean annual increment at biological rotation age in stand i under climate scenario $x$ and under baseline $b\left[\mathrm{~m}^{3} \cdot \mathrm{ha}^{-1} \cdot \mathrm{yr}^{-1}\right]$;

$x$ : climate scenario (minimum, median, maximum);

$m_{x}, m_{b}$ : number of stands under climate scenario $x$ and under baseline $b$.

\section{Results}

It is the primary objective of this simulation study to quantify the effect of long-term persistent dryer climates on forest productivity and to derive tangible recommendations for regional forest planning. Thus, we first compare volume increment under climate change to volume increment under constant current climate. The analysis based on mean values from single trees provides deeper insights into individual growth reactions to climate change. The innate age trend on volume increment is eliminated by looking at deviations. However, the absolute value of volume increment depends on initial tree dimension (c.f. Berrill and O'Hara 2014). Consequently, the larger the initial volume the more likely a large 
deviation between volume increment under climate change and constant climate will occur.

Five general findings are apparent when analyzing the climatic effects on mean single-tree volume increment over initial volume classes (Figs. 4 and 5). (1) The expected trend of larger deviations in absolute terms in larger initital volume classes is obvious for all species in both regions except for Scots pine in Uelzen. Accompanying, the uncertainty range prominently increases over initial volume classes, i.e. the differences in volume increment deviation among the three climate scenarios are relatively minor for small trees but increase to a significant extent for larger trees. (2) Climate change has a positive effect throughout initial volume classes in most cases in the first period. This effect diminishes or even reverses over time. (3) While the uncertainty range includes only positive deviations in most cases in the first period, the uncertainty range indicates positive as well as negative climate impacts on volume increment throughout initial volume classes in most cases in the second and third period. This is especially apparent for Scots pine in the third period and for European beech as well as oak in the second and third period in both regions. (4) Scots pine is the least sensitive species regarding the climatic effect on volume increment followed by oak and beech being affected the strongest (please observe the dashed lines in Figs. 4 and 5 indicating different scales of the vertical axes). (5) Furthermore, the climatic effect is stronger in Fläming than in Uelzen.

Deviations in mean single-tree volume increment over initial volume classes help to analyze climate effects on tree growth on the scale of biological productivity. However, the climatic effect on volume increment at the forest stand level might differ. Thus, it is also necessary to report results of deviations in periodic volume increment. On the scale of area productivity using periodic

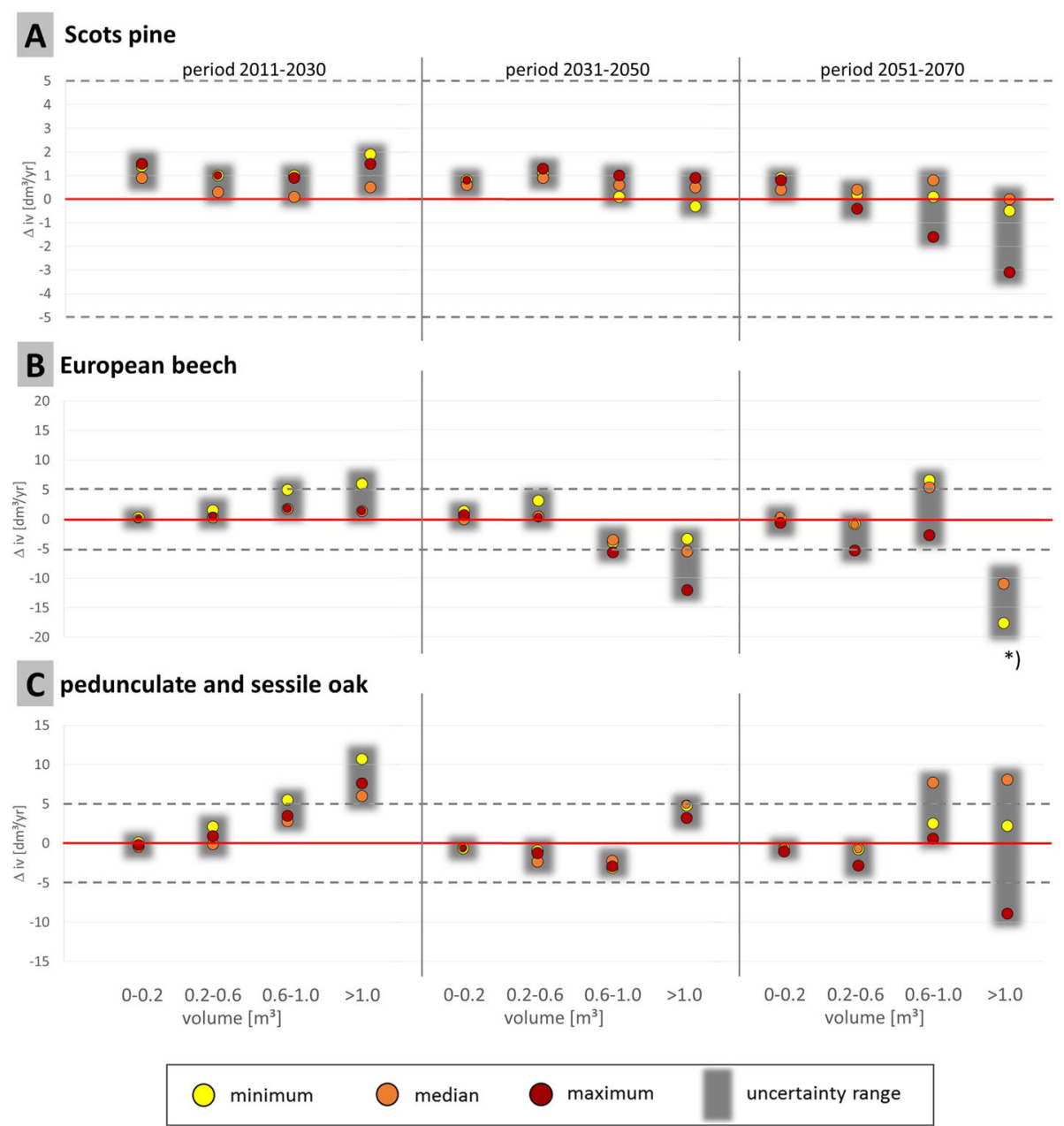

Fig. 4 Deviation in mean single-tree volume increment for different classes of initial single-tree volume between the respective climate scenario (minimum (yellow), median (orange) and maximum (dark red)) and the base line scenario for Scots pine (a), European beech (b) and Pedunculate and sessile oak (c) in Uelzen (blurred gray area indicates the uncertainty range; *) no observations under maximum climate scenario; dashed lines emphasize the $-5 \mathrm{dm}^{3} \cdot \mathrm{yr}^{-1}$ to $5 \mathrm{dm}^{3} \cdot \mathrm{yr}^{-1}$ range for better comparison due to unequal scaling of the vertical axes) 


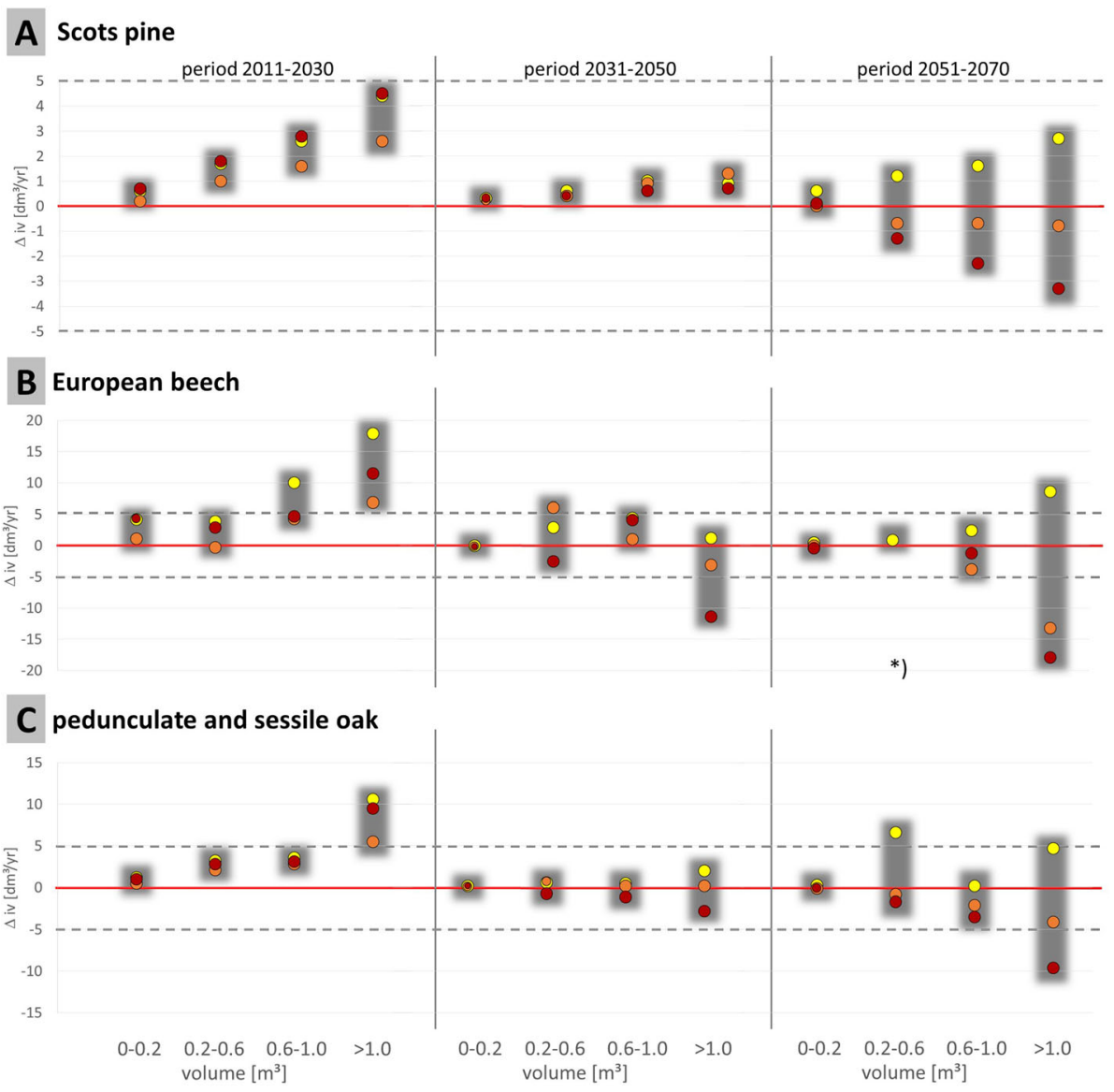

$\bigcirc$ minimum $\bigcirc$ median $\bigcirc$ maximum

Fig. 5 Deviation in mean single-tree volume increment for different classes of initial single-tree volume between the respective climate scenario (minimum (yellow), median (orange) and maximum (dark red)) and the base line scenario for Scots pine (a), European beech (b) and Pedunculate and sessile oak (c) in Flaeming (blurred gray area indicates the uncertainty range; *) no observations under median and maximum climate scenario; dashed lines emphasize the $-5 \mathrm{dm}^{3} \cdot \mathrm{yr}^{-1}$ to $5 \mathrm{dm}^{3} \cdot \mathrm{yr}^{-1}$ range for better comparison due to unequal scaling of the vertical axes)

volume increment more general tendencies of climatic effects on forest productivity can be identified (Fig. 6). As a reference we provide distributions on absolute values of periodic volume increment in the supplement (Additional file 2: Figures S1-S6).

The overall deviations in periodic volume increment displayed in Fig. 6 point out five general tendencies. (1) In accordance with the findings on mean single-tree volume increment periodic volume increment of all species benefits from climate change in the first projection period in both regions except for European beech and oak in Uelzen under the median and maximum scenario. (2) The uncertainty range widens over time and in most cases encompasses positive as well as negative deviations. Especially European beech strongly reacts on climate scenarios with positive deviations up to $2 \mathrm{~m}^{3} \cdot \mathrm{ha}^{-1} \cdot \mathrm{yr}^{-1}$ as well as negative values down to $-3 \mathrm{~m}^{3} \cdot \mathrm{ha}^{-1} \cdot \mathrm{yr}^{-1}$ in the third period. (3) Basically, the positive effect of climate change in the first period diminishes over time and even turns negative in many cases. While the deviation in periodic volume increment of Scots pine shows only a few small negative values in the third period, periodic volume increment of oak is negatively affected by climate change in Uelzen entirely but not so much in Fläming. The climate effect on periodic volume increment of European beech shows a disparate picture over time with positive tendencies under minimum and median climate scenario in Uelzen and a clearly negative trend under median and maximum climate scenario in Fläming. (4) Scots pine is the least sensitive species, both positive and negative. Climate change has the strongest impact on European beech with the most positive deviations in Fläming in the first period and the most negative deviations in Uelzen and Fläming in the third period. Oak takes on an intermediate position looking at the deviations in periodic volume increment. (5) Comparing both regions a stronger climate effect is 


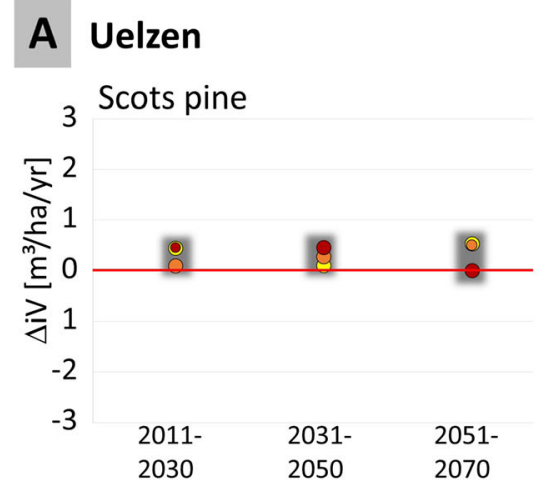

B Flaeming

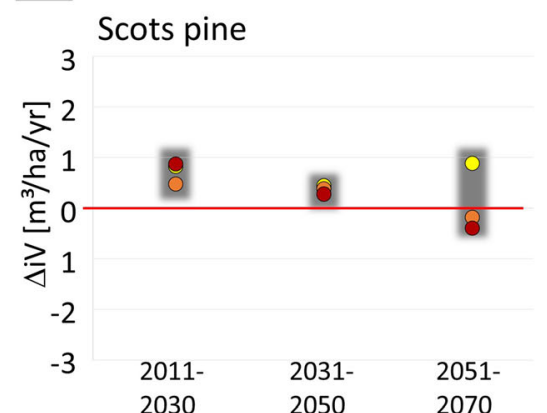

3 European beech

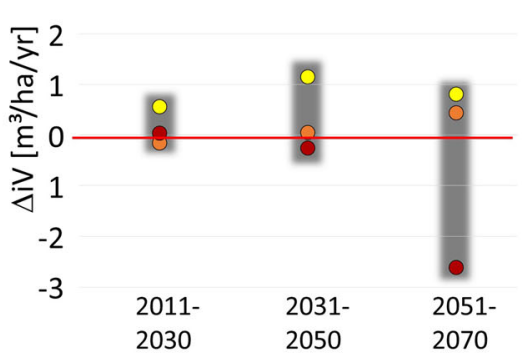

3 Pedunculate and sessile oak

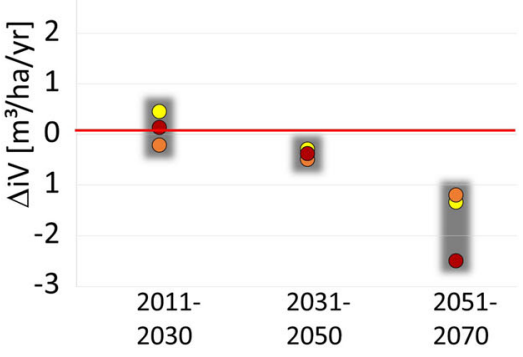

3

European beech

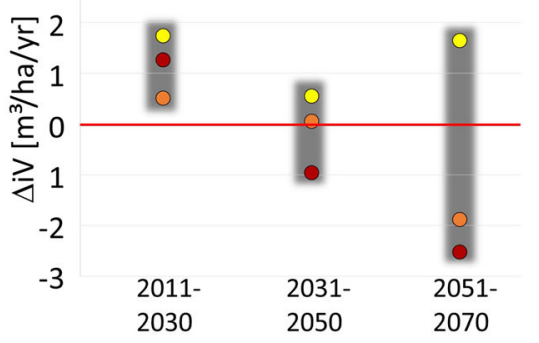

3

Pedunculate and sessile oak

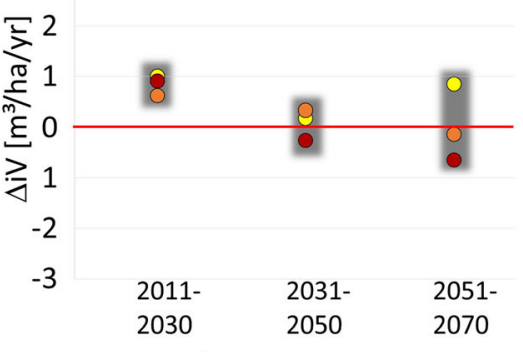

$\bigcirc$ minimum $\bigcirc$ median $\bigcirc$ maximum

Fig. 6 Overall deviation in periodic volume increment between the respective climate scenario (minimum (yellow), median (orange) and maximum (dark red)) and the base line scenario for Scots pine, European beech and Pedunculate and sessile oak in Uelzen (a) and Flaeming (b) (blurred gray area indicates the uncertainty range)

noticeable in Fläming looking at Scots pine and European beech. In Fläming the periodic volume increment of both species shows more positive reactions in the first period and under median and maximum scenario significant negative deviations in the third period. Periodic volume increment of pedunculate and sessile oak, however, is affected more heavily by climate change in Uelzen.

While the results displayed in Figs. 4, 5 and 6 emphasize the immediate short-term climatic effect on volume increment during the 20-year projection periods, the analysis of mean annual increment at biological rotation age $\left(M A I_{\max }\right)$ detects the cumulative long-term consequences of climate change on forest productivity. The differences in $M A I_{\max }$ indicate how the gradual divergences in volume growth between the baseline and the three climate scenarios accumulate to economically meaningful additional or fewer productivity, respectively (for absolute values on $M A I_{\text {max }}$ please refer to Additional file 2: Figures S1-S6).

In Uelzen Scots pine and oak both benefit with additional $M A I_{\text {max }}$ of up to $0.4 \mathrm{~m}^{3} \cdot \mathrm{ha}^{-1} \cdot \mathrm{yr}^{-1}$ depending on climate scenario and projection period (Fig. 7a). The projection only indicates a marginal loss for oak under maximum climate scenario in the third period. In Fläming the deviation in $M A I_{\max }$ shows similar patterns for pine and oak, however with slightly larger uncertainty ranges comprising larger positive values up to 0.6 $\mathrm{m}^{3} \cdot \mathrm{ha}^{-1} \cdot \mathrm{yr}^{-1}$ for pine $\left(0.25 \mathrm{~m}^{3} \cdot \mathrm{ha}^{-1} \cdot \mathrm{yr}^{-1}\right.$ for oak $)$ and negative values down to $-0.2 \mathrm{~m}^{3} \cdot \mathrm{ha}^{-1} \cdot \mathrm{yr}^{-1}$ for both species in the third period (Fig. 7b). While the uncertainty range increases significantly for both species in both regions over time, there is no obvious trend in productivity with increasing dyrer conditions until 2070. Contrary for European beech, the losses in $M A I_{\max }$ clearly increase over time. While beech productivity benefits from climate change in the first period in most cases with deviations in $M A I_{\max }$ up to $0.7 \mathrm{~m}^{3} \cdot \mathrm{ha}^{-1} \cdot \mathrm{yr}^{-1}$ in Uelzen and Fläming, there is a strong negative effect in Uelzen of down to $-1 \mathrm{~m}^{3} \cdot \mathrm{ha}^{-1} \cdot \mathrm{yr}^{-1}$ in the second and even down to $-3 \mathrm{~m}^{3} \cdot \mathrm{ha}^{-1} \cdot \mathrm{yr}^{-1}$ in the third projection period. In Fläming a similar trend for beech is observed with negative values down to $-0.8 \mathrm{~m}^{3} \cdot \mathrm{ha}^{-1} \cdot \mathrm{yr}^{-1}$ in the second and down to $-2 \mathrm{~m}^{3} \cdot \mathrm{ha}^{-1} \cdot \mathrm{yr}^{-1}$ in the third period. However, in Fläming under minimum climate scenario positive 


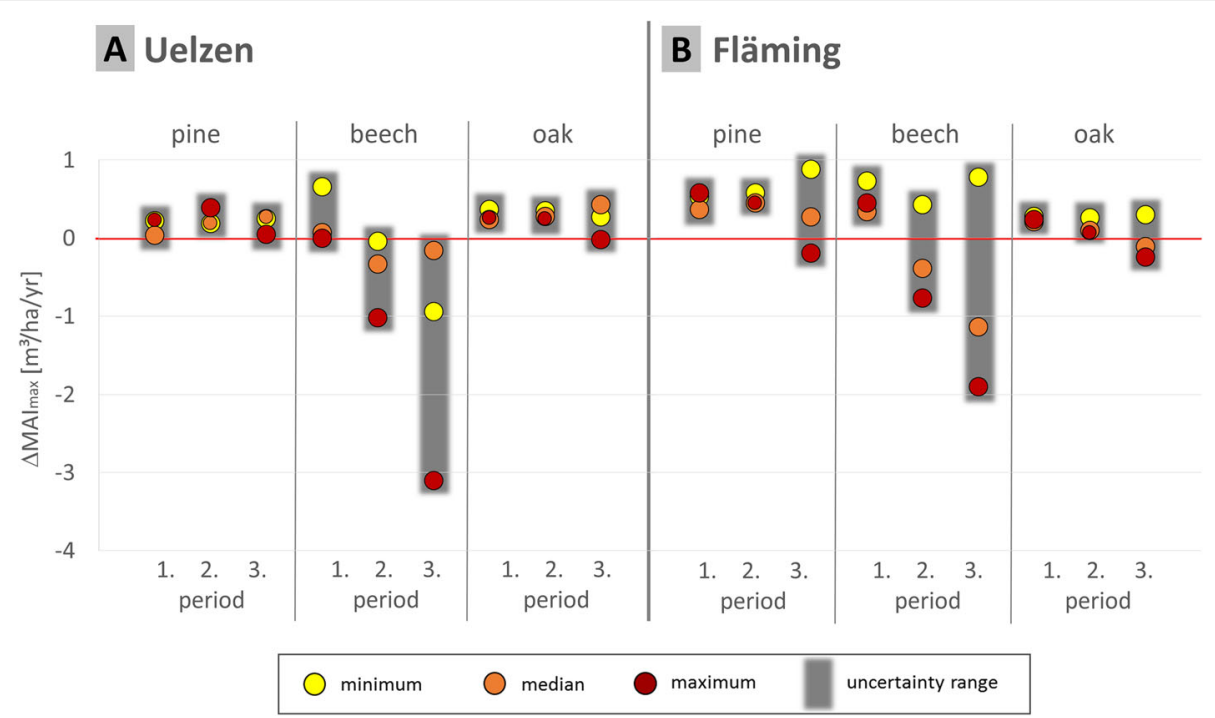

Fig. 7 Deviation in mean annual increment at biological rotation age $\left(M A I_{\text {max }}\right)$ between three climate scenarios and the baseline scenario for Scots pine, European beech and oak for ages 81 and older in Uelzen (a) and Fläming (b) in the first (2011-2030), second (2030-2051) and third (2051-2070) projection period

deviations in $M A I_{\max }$ of $0.4 \mathrm{~m}^{3} \cdot \mathrm{ha}^{-1} \cdot \mathrm{yr}^{-1}$ in the second period and even of $0.8 \mathrm{~m}^{3} \cdot \mathrm{ha}^{-1} \cdot \mathrm{yr}^{-1}$ in the third period are projected.

\section{Discussion}

Generally, simulation studies serve to evaluate future developments in the light of differing framework conditions (Clark et al. 2001). The main objective of simulation studies is to provide information beyond measurements and observations for forest planning and to support decision making. In contrast, resource assessments, field experiments and observational studies collect data and record forest conditions in the first place (Zhao et al. 2014). The measured data and the results and conclusions derived thereof are used for policy making, forest planning and resource allocation, hypothesis testing and modelling. Therefore, simulation studies on possible future developments and measurement data from different sources with a retrospective view may complement each other especially for forest planning issues under uncertainty.

The presented simulation study relies on current forest survey data which is then projected to assess forest development under climate change until 2070. The analysis of persistent dryer climate on forest growth and forest productivity reveals insights on three major issues.

(1) As a prerequisite for any decision support the effect of climate change on forest growth has to be quantified. Recommendations for adaptation measures cannot be derived before potential deviations between the current growth level and the projected growth level under climate change are assessed. Furthermore, it is crucial for reliable forest planning to take the uncertainty in projections into account. In view of the practical application of this simulation study the deviation in volume increment between constant climate and three climate scenarios for three species, Scots pine, European beech and Pedunculate and Sessile oak, is evaluated in two forest regions. Thus, the results show variations due to the variability in the initial forest and site conditions as well as the variability in the climate projections. The immediate, short-term effect of climate change on volume increment gives evidence of the growth model's sensitivity to the opposing climate factors, i.e. the positive influence of rising temperatures on growth and the inhibitory effect of reduced precipitation. In the near future of the first projection period the positive effect of rising temperatures ensures higher periodic volume increments of up to $2 \mathrm{~m}^{3} \cdot \mathrm{ha}^{-1} \cdot \mathrm{yr}^{-1}$ depending on species, region and climate scenario (cf. Fig. 6). However, in the projection period 2051 to 2070 the effect of persistent dryer conditions finally overcompensates the positive effect of higher temperatures in most cases in Uelzen and Fläming with losses up to $-3 \mathrm{~m}^{3} \cdot \mathrm{ha}^{-1} \cdot \mathrm{yr}^{-1}$. This quantitative comparison of periodic volume increment under constant and climate change conditions allows to evaluate species' productivity and future sitesuitability beyond a risk assessment alone. Specifically, in Uelzen beech will most likely suffer significant decreases in volume increment. Thus, 
persistent dryer conditions will strongly affect managing beech as a leading species on many sites. In the Fläming region, however, where beech predominantly serves as an admixed species already today (Albert et al. 2017), projected decreases in volume increment will be tolerable. On the other hand, Scots pine in pure and mixed stands dominates in both regions with proportions of almost $70 \%$ of the entire forest area in Uelzen and even 90\% in Fläming. Therefore, even small decreases in volume increment will amount to considerable losses in the regions. Similar to beech, oak only plays a minor role in both regions looking at the current proportions of 5\% in Uelzen and $4 \%$ in Fläming. However, even small potential decreases in volume increment might have a considerable impact on oak management in both regions as the economic value per cubic meter oak wood is high. While the analysis of single-tree and periodic volume increment in the three projection periods reveals the immediate impact of changing climatic conditions on forest growth, the evaluation of changes in $M A I_{\max }$ aims at the long-term, aggregating climatic effect on forest productivity. Basically, the results on periodic volume increment and $M A I_{\max }$ are in accordance. On average the productivity of all pine stands close to rotation age will profit from climate change until 2070, with the exception of the $M A I_{\max }$-value under maximum climate scenario in Fläming in the third projection period. Consequently, looking at overall productivity climate change does not negatively affect the management of Scots pine stands being harvested in Uelzen and Fläming until 2070. Contrary, persistent dryer climates heavily affect beech management with $M A I_{\max }$ losses up to $-3 \mathrm{~m}^{3} \cdot \mathrm{ha}^{-1} \cdot \mathrm{yr}^{-1}$ in Uelzen and $-2 \mathrm{~m}^{3} \cdot \mathrm{ha}^{-1} \cdot \mathrm{yr}^{-1}$ in Fläming. Especially in stands with beech as the leading species it might be necessary to adapt the management goals, e.g. to reduce the target diameter in order not to unduly extend rotation age. As a summary, the effect of climate change on the growth of Scots pine and European beech is quite similar looking at periodic volume increment and $M A I_{\max }$. However, small distinctions are obvious for oak. The reported losses in volume increment for oak in the second and third period in both regions are not as pronounced looking at $M A I_{\max }$. Especially in comparison to beech $M A I_{\max }$-values for oak indicate only minor losses (Fig. 7) while the negative deviations in periodic volume increment in the third period especially in Uelzen and under maximum climate scenario in Fläming seem considerable (Fig. 6). In the case of Uelzen, we explain this discrepancy with the cultivation effort of oak even on less favourable sites in the beginning of the 1970s. These oak stands seem to suffer under dryer conditions, thus, the deviations in periodic volume increment are negative. However, these stands are not included in the data used for $M A I_{\max }$ assessment because of the age restriction. On the other hand, the older oak stands mainly stock on sites which are not so much affected by dryer conditions, thus, deviations in $M A I_{\max }$ are positive.

(2) The second major issue of the presented analysis is to improve drought stress assessments with quantitative data on forest productivity. One common method to account for potential drought stress limitations when evaluating species for natural or artificial regeneration in northwestern Germany is a species-specific vulnerability assessment based on site water budget according to Grier and Running (1977), i.e. the sum of climatic water balance in the growing season (difference of precipitation and potential evapotranspiration for grass reference (Allen et al. 1998)) and the available water capacity (Spellmann et al. 2007, Spellmann et al. 2015). Generally, vulnerability is defined as the extent to which a system is susceptible to disturbances, or in our case how a forest ecosystem is affected by climate change (Füssel and Klein 2006). Specifically, drought vulnerability is related to exposition, i.e. duration and severity of water shortage, species' resilience against fluctuations in water availability and species' ability to adapt to climate-induced drought. Spellmann et al. (2007, Spellmann et al. 2015) assess drought stress by transferring ranges of site water budget into species-specific vulnerability classes (Table 2). The reasoning behind this method is that different tree species need a specific amount of water supply to achieve an economically advisable cultivation and management. And forest management is only economically promising, if the tree species show

Table 2 Definition of drought vulnerability classes for five major tree species (* Pedunculate and sessile oak) according to Spellmann et al. (2007, Spellmann et al. 2015)

\begin{tabular}{|c|c|c|c|c|}
\hline \multirow{2}{*}{$\begin{array}{l}\text { Drought } \\
\text { Vulnerability }\end{array}$} & \multicolumn{4}{|c|}{ Site water budget in growing season (mm) } \\
\hline & $\begin{array}{l}\text { Norway } \\
\text { spruce }\end{array}$ & $\begin{array}{l}\text { European } \\
\text { beech }\end{array}$ & oak* / Douglas-fir & Scots pine \\
\hline Low & $>0$ & $>-25$ & $>-150$ & $>-180$ \\
\hline Medium & 0 to -80 & -25 to -100 & -150 to -400 & -180 to -450 \\
\hline High & $<-80$ & $<-100$ & $<-400$ & $<-450$ \\
\hline
\end{tabular}


sufficient growth potential and potential risks do not exceed a certain level.

The values in Table 2 were derived from observations on species distribution ranges in combination with a qualitative assessment of cultivation risks. The cultivation risks comprise effects on growth, vitality and mortality. The values classify mean site conditions, i.e. not accounting for influencing factors such as topographic site exposition. The values indicate Norway spruce as most prone to drought vulnerability, followed by European beech, oak and Douglas-fir and Scots pine as most resistant. An example illustrates how results from a drought vulnerability assessment following the method proposed by Spellmann et al. (2007, Spellmann et al. 2015) can valuably be amended by quantitative information on future species productivity. In a former study, we evaluated the necessity of adapting tree species selection in Uelzen and Fläming taking drought restrictions into account (Albert et al. 2017). For Uelzen we concluded that the number of Scots pine dominated stands will increase from $60 \%$ refraining from drought limitations to $69 \%$ under medium climate scenario and even $80 \%$ under maximum climate scenario until 2070 (under minimum climate scenario the proportion is estimated to be constant). This strong preference of Scots pine in future tree species selection based simply on drought vulnerability limits is in line with the current analysis that no severe losses neither for periodic volume increment (Fig. 6) nor for $M A I_{\max }$ (Fig. 7) are to be expected. For oak, however, a recommended slight increase from $7 \%$ under the assumption of sufficient water supply to $8 \%$ under maximum climate scenario might be challenged looking at the projected future productivity. If the productivity goal is rated high in the decision process, potential losses in periodic volume increment of up to $-2.5 \mathrm{~m}^{3} \cdot \mathrm{ha}^{-1} \cdot \mathrm{yr}^{-1}$ might influence the decision process on species selection towards more productive species under climate change although oak qualifies as a species to be cultivated under the drought vulnerability limits. Evaluating European beech requires a different line of reasoning. In our species selection study we expected the proportion of beech dominated stands in Uelzen to drop from $16 \%$ with no assumed drought limitations to $14 \%$ under minimum, and an insignificant $2 \%$ under median and maximum climate scenario. While these recommendations are based solely on the intrinsic and fuzzy approach transferring expert-knowledge of species' productivity and risks into drought vulnerability classes we complement and confirm these results with sound information on projected substantial losses for beech looking at periodic volume increment and $M A I_{\max }$ under climate change in Uelzen.

In summary, as forest growth is projected as a function of several climatic and soil properties the derived results of the presented study complement the drought vulnerability assessment of Table 2 beyond evaluating the site water budget alone. The quantitative statement on potential productivity losses, including an uncertainty range which depends on the assumed climate projections and the time horizon, enriches the information basis for forest planning decisions in the light of persistent dryer climates.

(3) It is another objective to evaluate the approach's potential to derive conclusions for forest management and to formulate adaptation strategies using the two regions Uelzen and Fläming as an example. First of all, our results correspond to the perception by Kätzel and Höppner (2011) who conclude that Scots pine will persist as an important and economically meaningful species for forest management in the northeastern German lowlands and that oak and beech will show different reactions to climate change depending on other environmental factors. Our results also confirm findings by Bauwe et al. (2015) who predicted the radial growth response to climate change of Scots pine, European beech and Pedunculate oak along a precipitation gradient in northeastern Germany. As in our analysis growth rates for beech and oak were projected to decrease under the A1B climate scenario until 2100 while Scots pine showed slight growth increase as well as decrease depending on site and location (as a reference, A1B is best comparable to RCP 6.0). A broad study on sustainable land use management by Spellmann et al. (2017) specifically recommends to promote climate-adapted tree species and species mixtures for future forest generations in order to lower and distribute potential future risks in Uelzen. Furthermore, the already completed advance planting of beech should be enriched with natural regeneration of more drought tolerant species such as oak, Scots pine and birch or even by planting Douglas-fir, Grand fir or red oak in beech gaps. Our analysis clearly supports the recommendations by Spellmann et al. to promote Scots pine and critically question the future role of beech in Uelzen. However, our results on potential productivity losses in the case of oak at least relativize its 
importance for forest management in Uelzen. In any case, it is crucial in forest planning to implement tree species selection for future stands as a case-by-case decision. In the same study, Spellmann et al. conclude for the Fläming region that the increasingly dryer conditions will also negatively affect Scots pine. Our results on periodic volume increment seem to support this assessment. However, the silvicultural scope in tree species selection is limited in Fläming, thus, it is most advisable to promote mixed forests, i.e. mainly leading Scots pine or Douglas-fir with admixtures of beech or oak.

\section{Assumptions and model limitations}

In this study the interaction between the site-sensitive longitudinal height-diameter model and the basal area increment model as well as other functionalities, e.g. mortality and ingrowth, within the framework of the growth simulator WaldPlaner plays a major role. The interpretation of our simulation results is subject to various assumptions and model limitations.

(1) First of all, the results are only valid for conditions specified by the applied growth functions, i.e. the model functionalities and the parameterization basis, and in the range of the assumed climate projections. The site-sensitive height-diameter model is parameterized for the entire area of Germany. The other growth functions of the WaldPlaner framework are parameterized for northwestern Germany. Thus, the spatial scope in this study is well covered. Furthermore, the height-diameter model is a statistical model fit on past observations. This implies two possible pitfalls. First, under climate change the parameter values might well be in the extrapolation range with unsuspected model behavior. However, biologically feasible results were obtained in various sensitivity studies on the model (Schmidt 2010; Albert and Schmidt 2014). Second, the model philosophy assumes that the significance of the selected model parameters has the same explanatory power under future climatic conditions. However, under more extreme climate conditions other factors could strongly influence forest growth. For example, Michelot et al. (2012) compared growth reactions of European beech, sessile oak and Scots pine to climatic variations and soil water deficits in France. Their findings clearly show that growth of beech and Scots pine will be determined by mainly summer maximum temperatures and precipitation in the growing season also under future climate conditions, whereas oak growth will be strongly affected by autumn droughts due to tree carbohydrate storage depletion. In this case, with increasing autumn drought stress and a higher frequency of extreme drought events during that season in the future a new parameter, e.g. autumn water deficit, would presumably be significant in modelling growth. These possible shifts on parameter significance and interactions under climate change are beyond the capabilities of statistical model approaches. But we assume that the broad range of observed climate values and especially different combinations on temperature and aridity index in the past throughout Germany covers or is close to projected future conditions for the large part.

The simulation results strongly rely on the climate projections, which in turn depend on the applied regional climate model STARS (Orlowsky et al. 2008). Independent from the three climate scenarios resulting from three different global circulation models (GCM), STARS always projects climate patterns with dryer summers and wetter winters in Germany under any scenario. These climate patterns stimulate the presented impact analysis. These uniform climate patterns originate from a specific temperature-driven resampling algorithm (TCR) being used for climate projections by the statistical model STARS. The GCMs define the temperature forcing as a periodic trend. TCR generates a new sequence of annual climate values according to the temperature forcing in a first step. In a second step 12-day-weather sequences are newly arranged. Wechsung and Wechsung $(2014,2015)$ criticized the underlying assumption by Gerstengarbe et al. (2013) to validate STARS based on mean statistical estimates during the period 1951 to 1975 in comparison to a new period with newly arranged values using TCR. Moreover, Wechsung and Wechsung (2014, 2015) prove a negative bias in STARS' projections of precipitation of $5 \%$ per $1^{\circ} \mathrm{C}$ temperature increase. Nevertheless, accepting the model limitations and regarding the type of climate change projection Wechsung and Wechsung (2014) recommend STARS to be used in climate impact studies. Therefore, we employ STARS' climate projections in the presented impact study in lack of alternative available data, knowing about potential pitfalls.

(2) Conclusions on the results are only permitted under the assumption that the scope of future 
climate conditions is within the quantified uncertainty range of the climate projections. The knowledge on the likelihood of a certain climatic development is low. Therefore, probabilities cannot be assigned whether or not certain climate conditions will be realized (Foley 2010). As a consequence scenario analysis employing climate ensembles is utilized to quantify a range of possible outcomes. This range defines the uncertainty in climate modelling. However, this approach falls short to cover the uncertainty in its entirety as beyond scenario analysis which assumes certain boundary conditions there is a considerable amount of uncertainty left due to the lack of any knowledge that originates from the long time scales and complexity, termed deep uncertainty (Walker et al. 2003; Kandlikar et al. 2005). Knutti and Sedláček 2012 reported on the robustness and uncertainties in the Coupled Model Intercomparison Project Phase 5 (CMIP5) by the World Climate Research Programme. They conclude that in spite of tremendous improvements of the climate models and higher spatial resolutions the projection uncertainties did not decrease compared to successive IPCC reports. Hence, Knutti and Sedláček (2012) advise to account for the uncertainties when deriving decision support from climate impact analysis. Our reported analysis reflects climate projection uncertainties by applying three climate scenarios which is a compromise between adequate computational workload and sufficient consideration of possible projection uncertainties. Informed recommendations for forest planning thus are possible, however, any conclusion derived from impact analysis must remain highly conditional on the underlying ranges of climate projections. But at best, conclusions drawn are robust, e.g. in Uelzen under each of the three applied climate scenarios the deviation in $M A I_{\max }$ indicates a consistent positive climate effect for Scots pine and, contrary for European beech, a consistent negative effect in the third period (Fig. 7). Therefore, any decision in favor of Scots pine management will result in higher productivity. And the other way around, any decision to the disadvantage of beech management, e.g. turning away from the currently common practice of converting Scots pine stands into stand types with leading beech or even an earlier conversion of current beech stands to more productive species, are justified by losses in $M A I_{\max }$.

(3) The dynamics in climate parameters are accounted for in the height development, although the height-diameter model is strictly speaking static. The climate effect on basal area growth, however, is indirect as the predictor crown surface area is estimated based on tree height. As analyzed in this study, the growth model is capable to reproduce effects of persistent dryer climate conditions on forest productivity in a long-term perspective. One shortcoming of the growth model is that disturbances such as extreme short-term drought events are neglected. The impact of severe dry spells on tree growth was confirmed in numerous studies (e.g. Orwig and Abrams 1997; Klos et al. 2009; Michelot et al. 2012; Weber et al. 2013). In summary, both the growth reactions to long-term trends and the consequences of disturbances are important factors to adequately project forest development. Lindner et al. (2014) stated in this context that not accounting for extreme events might explain the deviations between observed growth trends and growth projections in many cases. Nevertheless, decision support for forest planning and specifically in the assessment of species suitability can be granted based on projections of species productivity as shown in the impact study in combination with a sound vulnerability analysis accounting for possible disturbances, for instance an increasing frequency of extreme drought events.

Ecophysiological processes such as interactions between competition, species mixture, pathogens, nitrogen deposition or elevated $\mathrm{CO}_{2}$ levels with drought stress are also not accounted for in the applied growth model. Evidence for these interactions are provided by several studies. For example, Giuggiola et al. (2013) reported for Scots pine on xeric sites in Switzerland that a strong reduction in basal area of $40 \%$ to $60 \%$ of the regular management regime mitigated drought effects. On the issue of species mixture Arthur and Dech (2016) contributed further findings that species mixtures have a significant influence on the effects of drought on forest growth. The hypothesis that species composition can mitigate drought effects was also supported by Pretzsch et al. (2013). On the other hand, Thurm et al. (2016) showed for Douglas-fir and European beech mixed stands that not all species equally profit from mixtures looking at drought stress release. In their study Thurm et al. (2016) provided evidence that in mixture Douglasfir is positively affected while beech shows a higher sensitivity to climate impacts.

Besides the direct interaction of tree or stand properties on drought stress also external factors 
may alter the impact of drought on forest growth. A strong interaction between drought and pathogens and, eventually, with tree vitality, growth and even mortality exists (e.g. Desprez-Loustau et al. 2006; Overbeck and Schmidt 2012; Schoneberg 2017). There is still a great uncertainty about the direction and the magnitude in the response of insects and fungi to drought (Jactel et al. 2011). But as drought causes physiological changes in tree defenses it will alter the patterns and effects of biotic disturbances (Ayres and Lombardero 2000). Consequently, the interaction of drought and pathogens will affect tree growth and tree vitality (Dobbertin 2005).

Increased nitrogen deposition has a fertilizing effect on forest growth (Hyvönen et al. 2007; Kahle et al. 2008a). Then again, the positive effect of nitrogen does not apply to all sites equally (e.g. Näsholm et al. 2000). Furthermore, some studies suggest that nitrogen fertilization might have a negative effect on root growth and might increase root mortality, thus reducing tree vitality (Clemensson-Lindell and Persson 1995a, 1995b; Persson and Ahlström 2002). Moreover, it is speculated if higher nitrogen availability causes higher drought risks (e.g. Näsholm et al. 2000; Dziedek et al. 2016). A similar line of reasoning applies to the issue of elevated $\mathrm{CO}_{2}$-concentration. Several studies analyzed the effect of elevated $\mathrm{CO}_{2}$-concentration on forest growth, unfortunately with no consistent findings (e.g. Hättenschwiler et al. 1997; Körner 2006; Handa et al. 2006; Kahle et al. 2008b). Recently, simulation studies indicated the high sensitivity of forest growth to assumed future $\mathrm{CO}_{2}$ increase (Reyer et al. 2014; Lindner et al. 2014; Schelhaas et al. 2015). The assessment of interactions between elevated $\mathrm{CO}_{2}$-concentration and drought is even more sophisticated.

Hättenschwiler et al. (1997), Ellsworth (1999) and Körner (2006) reported a possibly beneficial impact of elevated $\mathrm{CO}_{2}$ on tree growth under drought conditions. Some studies indicated a higher wateruse efficiency of trees as the main reason for a positive effect of higher $\mathrm{CO}_{2}$ under drought stress (e.g. Battipaglia et al. 2013; Keenan et al. 2013). Contrary, Tognetti et al. (2000) found no evidence for growth response to increasing $\mathrm{CO}_{2}$ during drought stress for five Mediterranean forest tree species. All the above mentioned interactions could alter tree growth under extreme drought events and even under a persistent dryer climate. More research is needed to include these effects in growth models to improve informed decision support for forest management. Ciais et al. (2005) clarified the extent of the implications as they assumed that extreme drought events and persistent dryer conditions might significantly alter the long-term carbon balances and reverse forests from sinks to sources in Europe.

\section{Conclusions}

This study illustrates a method to assess the long-term effects of persistent dryer climate conditions on forest growth and productivity by comparing mean single-tree volume increment, periodic volume increment and mean annual increment at biological rotation age $\left(M A I_{\text {max }}\right)$ under constant climate conditions and under three climate projections until 2070. The projected changes in forest growth within a specified uncertainty range serve as quantitative contributions to provide decision support in forest planning, e.g. adapting silvicultural management strategies, evaluating species future site suitability and assessing the impact on timber supply. The quantitative analysis of possible productivity changes under persistent dryer climate complements the expertknowledge based drought vulnerability assessment which is applied in northwestern Germany today (cf. Table 2). The drought vulnerability assessment as a synoptic approach qualitatively aggregates the effects of drought on tree growth, vitality and mortality based on thresholds for site water budget. The reported projection of productivity changes quantifies effects of persistent dryer climates on forest growth separately. In addition, the effects of drought on vitality and mortality still needs to be quantified on a level suitable for forest management.

In particular, on the grounds of the specific simulation results following conclusions for forest planning in the two regions can be drawn: (1) Although the uncertainty range in the third period (2051 to 2070) encompasses positive as well as negative effects on volume increment in many cases for European beech, pedunculated and sessile oak and Scots pine in both regions decisions on species suitability have to be made. In this case, differences in site conditions need to be taken into account and furthermore the decision also is a question of risk attitude. The results presented are average values for all sites considered. Thus, favourable site conditions, e.g. sufficient available water capacity, might well compensate the negative effect of persistent dryer climates and different recommendations for these sites apply. (2) Scots pine is rated as the least sensitive species to dryer climate conditions. $M A I_{\max }$ of Scots pine even increases in the time period and regions under consideration. Thus, from the growth and yield point of view Scots pine will be well suited for forest management in the future. The same but not quite as pronounced applies to the management of oak in the Fläming region while being doubtful in Uelzen. (3) European beech faces the 
most severe growth reductions. In stands with beech as the leading species the negative impact of climate change might call for silvicultural adaptation measures and a change in species in the next forest generation. On sites, where a vulnerability analysis does not exclude beech from cultivation, forest management with beech as an admixture species is still advisable at the cost of lower productivity. (4) The clear temporal trend in magnitude and direction of the effect of persistent dryer climates on forest growth and productivity has to be considered.

\section{Additional files}

Additional file 1: Table S1. Characteristic numbers for the collectives under baseline (base) and minimum (min), median (med) and maximum (max) climate scenario for Uelzen at the end of the respective period (for age, dbh and height $1^{\text {st }}$ quantile, median (med) and $3^{\text {rd }}$ quantile values are given). Table S2. Characteristic numbers for the collectives under baseline (base) and minimum (min), median (med) and maximum (max) climate scenario for Fläming at the end of the respective period (for age, $\mathrm{dbh}$ and height $1^{\text {st }}$ quantile, median (med) and $3^{\text {rd }}$ quantile values are given). (DOCX $28 \mathrm{~kb}$ )

Additional file 2: Figure S1. Boxplots of periodic volume increment (upper row) and mean annual increment at biological rotation age (lower row) under baseline (gray), minimum (yellow), median (orange) and maximum (red) climate scenario for European beech in Uelzen (included are only stands with beech as a leading species). Figure S2. Boxplots of periodic volume increment (upper row) and mean annual increment at biological rotation age (lower row) under baseline (gray), minimum (yellow), median (orange) and maximum (red) climate scenario for Pedunculate and sessile oak in Uelzen (included are only stands with oak as a leading species). Figure S3. Boxplots of periodic volume increment (upper row) and mean annual increment at biological rotation age (lower row) under baseline (gray), minimum (yellow), median (orange) and maximum (red) climate scenario for Scots pine in Uelzen (included are only stands with Scots pine as a leading species). Figure S4. Boxplots of periodic volume increment (upper row) and mean annual increment at biological rotation age (lower row) under baseline (gray), minimum (yellow), median (orange) and maximum (red) climate scenario for European beech in Fläming (included are only stands with beech as a leading species). Figure S5. Boxplots of periodic volume increment (upper row) and mean annual increment at biological rotation age (lower row) under baseline (gray), minimum (yellow), median (orange) and maximum (red) climate scenario for Pedunculate and sessile oak in Fläming (included are only stands with oak as a leading species). Figure S6. Boxplots of periodic volume increment (upper row) and mean annual increment at biological rotation age (lower row) under baseline (gray), minimum (yellow), median (orange) and maximum (red) climate scenario for Scots pine in Fläming (included are only stands with Scots pine as a leading species). (ZIP $1002 \mathrm{~kb})$

\section{Abbreviations}

ari: Aridity index; awc: Available water capacity; bai: Basal area increment; c66: Competition index at 66\% of tree height from top; c66c: Change in competition index c66; csa: Crown surface area; cwb: Climatic water balance; dbh: Diameter at breast height; GCM: Global circulation model; gs: Growing season; gw: Groundwater class; iv: Periodic volume increment; iv: Volume increment of single tree; $\mathrm{MAI}_{\max }$ : Mean annual increment at biological rotation age; nut: Soil nutrient class; RCP: Representative concentration pathway; SI: Site index at reference age 100; TCR: Temperature-driven resampling algorithm; tsum: Temperature sum

\section{Acknowledgements}

The authors wish to thank two anonymous reviewers who contributed greatly with their valuable comments to improve the manuscript.

\section{Funding}

The presented research was funded by the German Federal Ministry of Education and Research under research grant $033 \mathrm{~L} 029 \mathrm{H}$ and is part of the interdisciplinary research project "Sustainable land-use management in the North German lowlands".

\section{Availability of data and materials}

The datasets used and/or analysed during the current study are available from the corresponding author on reasonable request.

\section{Authors' contributions}

The first author (MA) conducted the data analysis and wrote the first draft. RN was mainly involved in interpreting the simulation results and deriving silvicultural conclusions as well as recommendations for forest management. MS provided the site-sensitive height-diameter model and contributed to the methods and data analysis significantly. JS substantially contributed to the method to assess drought stress. All authors jointly discussed the results, drew conclusions and finalized the manuscript. All authors read and approved the final manuscript.

\section{Authors' information}

MA and MS are senior forest researchers at the Northwest German Forest Research Institute, Department of Forest Growth. They both have long-term experience in growth modelling and are especially interested in the impact of changing climate conditions on forest growth. RN, also senior forest researcher at the Department of Forest Growth, is an expert in long-term forest growth experiments and he has a strong background in silviculture and forest planning. JS is a senior researcher at the Northwest German Forest Research Institute, Department of Environmental Control, specializing in climate and water budget modelling.

Ethics approval and consent to participate

Not applicable

\section{Consent for publication}

Not applicable.

\section{Competing interests}

The authors declare that they have no competing interests.

\section{Author details}

'Department of Forest Growth, Northwest German Forest Research Institute, Göttingen, Germany. ${ }^{2}$ Department of Environmental Control, Northwest German Forest Research Institute, Göttingen, Germany.

Received: 13 June 2018 Accepted: 3 September 2018

Published online: 08 October 2018

\section{References}

Adams HD, Guardiola-Claramonte M, Barron-Gafford GA, Villegas JC, Breshears DD, Zou CB, Troch PA, Huxman TE (2009) Temperature sensitivity of drought-induced tree mortality portends increased regional die-off under global-change-type drought. Proc. Natl Acad Sci U S A 106(17):7063-7066. https://doi.org/10.1073/pnas.0901438106

Aertsen W, Janssen E, Kint V, Bontemps J-D, Van Orshoven J, Muys B (2014) Long-term growth changes of common beech ( Fagus sylvatica $L$.) are less pronounced on highly productive sites. Forest Ecol Manage 312:252-259. https://doi.org/10.1016/j.foreco.2013.09.034

Albert M, Hansen J, Nagel J, Schmidt M, Spellmann H (2015) Assessing risks and uncertainties in forest dynamics under different management scenarios and climate change. For Ecosystems 2(1):14. https://doi.org/10.1186/s40663-0150036-5

Albert M, Leefken G, Nuske RS, Ahrends B, Sutmöller J, Spellmann H (2016) Auswirkungen von klimatischer Unsicherheit auf die Forstplanung am Beispiel von vier Regionen im norddeutschen Tiefland. Allg Forst Jagdztg 187(9/10):161-185

Albert M, Nagel R-V, Nuske RS, Sutmöller J, Spellmann H (2017) Tree Species Selection in the Face of Drought Risk - Uncertainty in Forest Planning. Forests 8(363). https://doi.org/10.3390/f8100363

Albert M, Schmidt M (2014) Sensitivität von Waldentwicklungsprojektionen gegenüber Klimaszenarien und Nutzungsstrategien. In: Klädtke $U$, Kohnle U 
(eds) Deutscher Verband Forstlicher Forschungsanstalten. Sektion Ertragskunde. Annual conference, Lenzen a.d. Elbe, pp 30-43

Albrecht A, Duran-Rangel C, Kändler G, Schmidt M, Yue C, Kohnle U (2017) Evaluierung verschiedener klimasensitiver Bonitätsmodelle für Fichte. In: Klädtke U, Kohnle U (eds) Deutscher Verband Forstlicher Forschungsanstalten. Sektion Ertragskunde. Annual conference, Untermarchtal, pp 59-69

Allen CD, Macalady AK, Chenchouni H, Bachelet D, McDowell NG, Vennetier M, Kitzberger T, Rigling A, Breshears DD, Hogg EHT, Gonzales P, Fensham R, Zhang Z, Castro J, Demidova N, Lim J, Allard G, Running SW, Semerci A, Cobb N (2010) A global overview of drought and heat induced tree mortality reveals emerging climate change risk for forests. Forest Ecol Manage 259(4):660-684. https://doi.org/10.1016/j.foreco.2009.09.001

Allen RG, Pereira LS, Raes D, Smith M, Ab W (1998) Crop evapotranspiration Guidelines for computing crop water requirements (FAO Irriga). FAO, Rome

Anderegg LDL, Anderegg WRL, Berry JA (2013) Not all droughts are created equal: translating meteorological drought into woody plant mortality. Tree Physiol 33(7):701-712. https://doi.org/10.1093/treephys/tpt044

Arthur CM, Dech JP (2016) Species composition determines resistance to drought in dry forests of the Great Lakes - St. Lawrence forest region of central Ontario region of central Ontario. J Veg Sci. https://doi.org/10.1111/jvs.12416

Ayres MP, Lombardero MJ (2000) Assessing the consequences of global change for forest disturbance from herbivores and pathogens. Sci Total Environ 262: 263-286

Barber VA, Juday GP, Finney BP (2000) Reduced growth of Alaskan white spruce in the twentieth century from temperature-induced drought stress. Nature 405(6787):668-673. https://doi.org/10.1038/35015049

Battipaglia G, Saurer M, Cherubini P, Calfapietra C, McCarthy HR, Norby RJ, Cotrufo MF (2013) Elevated $\mathrm{CO}_{2}$ increases tree-level intrinsic water use efficiency : Insights from carbon and oxygen isotope analyses in tree rings across three forest FACE sites. New Phytol 197:544-554. https://doi.org/10. 1111/nph.12044

Bauwe A, Jurasinski G, Scharnweber T, Schröder C, Lennartz B (2015) Impact of climate change on tree-ring growth of Scots pine, common beech and pedunculate oak in northeastern Germany. iForest - Biogeosci For. https:// doi.org/10.3832/ifor1421-008

Berrill J-P, O'Hara KL (2014) Estimating site productivity in irregular stand structures by indexing the basal area or volume increment of the dominant species. Can J Forest Res 44:92-100. https://doi.org/10.1139/cjfr-2013-0230

Bi D, Dix M, Marsland SJ, O'Farrell S, Rashid HA, Uotila P, Hirst AC, Kowalczyk E, Golebiewski M, Sullivan A, Yan H, Hannah N, Franklin C, Sun Z, Vohralik P, Watterson I, Zhou X, Fiedler R, Collier M, Ma Y, Noonan J, Stevens L, Uhe P, Zhu H, Griffies SM, Hill R, Harris C, Puri K (2013) The ACCESS coupled model: description, control climate and evaluation. Austr Meteorol Oceanogr J 63:41-64

Bigler C, Bräker OU, Bugmann H, Dobbertin M, Rigling A (2006) Drought as an Inciting Mortality Factor in Scots Pine Stands of the Valais, Switzerland. Ecosystems 9:330-343. https://doi.org/10.1007/s10021-005-0126-2

Böckmann T, Spellmann H, Hüsing F (1998) Neukonzeption und Weiterentwicklung der Forsteinrichtung in den Niedersächsischen Landesforsten. Forst und Holz 53(10):298-302

Boisvenue C, Running SW (2006) Impacts of climate change on natural forest productivity - Evidence since the middle of the 20th century. Global Change Biol 12(5):862-882. https://doi.org/10.1111/j.1365-2486.2006.01134.x

Brang P, Bugmann H, Bürgi A, Mühlethaler U, Rigling A, Schwitter R (2008) Klimawandel als waldbauliche Herausforderung. Schweiz Z Forstwes 159(10): 362-373. https://doi.org/10.3188/szf.2008.0362

Choat B, Jansen S, Brodribb TJ, Cochard H, Delzon S, Bhaskar R, Bucci SJ, Feild TS, Gleason SM, Hacke UG, Jacobsen AL, Lens F, Maherali H, Martinez-Vilalta J, Mayr S, Mencuccini M, Mitchell PJ, Nardini A, Pittermann J, Pratt RB, Sperry JS, Westoby M, Wright IJ, Zanne AE (2012) Global convergence in the vulnerability of forests to drought. Nature 491:752-756. https://doi.org/10.1038/nature11688

Ciais P, Reichstein M, Viovy N, Granier A, Ogee J, Allard V, Aubinet M, Buchmann N, Bernhofer C, Carrara A, Chevallier F, De Noblet N, Friend AD, Friedlingstein P, Grunwald T, Heinesch B, Keronen P, Knohl A, Krinner G, Loustau D, Manca G, Matteucci G, Miglietta F, Ourcival JM, Papale D, Pilegaard K, Rambal S, Seufert G, Soussana JF, Sanz MJ, Schulze ED, Vesala T, Valentini R (2005) Europe-wide reduction in primary productivity caused by the heat and drought in 2003. Nature 437(7058):529-533. https://doi.org/10.1038/ nature03972

Clark JS, Carpenter SR, Barber M, Collins S, Dobson A, Foley JA, Lodge DM, Pascual M, Pielke R Jr, Pizer W, Pringle C, Reid W, Rose KA, Sala OE,
Schlesinger WH, Wall DH, Wear D (2001) Ecological forecasting: an emerging imperative. Science 293(2001):657-660. https://doi.org/10.1126/science.293. 5530.657

Clemensson-Lindell A, Persson H (1995a) Fine-root vitality in a Norway spruce stand subjected to various nutrient supplies. Plant Soil 168(1):167-172. https://doi.org/10.1007/BF00029325

Clemensson-Lindell A, Persson H (1995b) Nitrex The effects of nitrogen addition and removal on Norway spruce fine-root vitality and distribution in three catchment areas at Gårdsjön. Forest Ecol Manage 71(1):123-131. https://doi. org/10.1016/0378-1127(94)06089-2

de Martonne E (1926) Une nouvelle fonction climatologique: l'indice d'aridité. La Météorologie 21:449-458

Desprez-Loustau M-L, Marcais B, Nageleisen L-M, Piou D, Vannini A (2006) Interactive effects of drought and pathogens in forest trees. Ann Forest Sci 63:597-612

Dobbertin M (2005) Tree growth as indicator of tree vitality and of tree reaction to environmental stress : a review. Eur J Forest Res 124:319-333. https://doi. org/10.1007/s10342-005-0085-3

Dziedek C, Härdtle W, von Oheimb G, Fichtner A (2016) Nitrogen Addition Enhances Drought Sensitivity of Young Deciduous Tree Species. Front Plant Sci 7(1100). https://doi.org/10.3389/fpls.2016.01100

Ellsworth DS (1999) CO $\mathrm{CO}_{2}$ enrichment in a mature pine forest: are $\mathrm{CO}_{2}$ exchange and water status in the canopy affected? Plant Cell Environ 22:461-472

Falk W, Mellert K, Bachmann-Gigl U, Kölling C (2013) Bäume für die Zukunft : Baumartenwahl auf wissenschaftlicher Grundlage. LWF Aktuell 94:8-11

Fleck S, Albert M, Plasil P, Nagel R-V, Sutmöller J, Ahrends B, Schmidt M, Evers J, Hansen J, Overbeck M, Schmidt W, Spellmann H, Meesenburg H (2015) Pilotstudie zu den lokalen Auswirkungen des Klimawandels auf die Forstwirtschaft in ausgewählten Regionen Sachsen-Anhalts. Beiträge aus der NW-FVA, Band 13, Göttingen

Foley AM (2010) Uncertainty in regional climate modelling: A review. Progress Phys Geogr 34(5):647-670. https://doi.org/10.1177/0309133310375654

Frich P, Alexander LV, Della-Marta P, Gleason B, Haylock M, Tank Klein AMG, Peterson $T$ (2002) Observed coherent changes in climatic extremes during the second half of the twentieth century. Climate Res 19(3):193-212. https:// doi.org/10.3354/cr019193

Füssel H-M, Klein RJT (2006) Climate Change Vulnerability Assessments: An Evolution of Conceptual Thinking. Climatic Change 75:301-329. https://doi. org/10.1007/s10584-006-0329-3

Gerstengarbe F-W, Werner PC, Österle H, Burghoff O (2013) Winter storm- and summer thunderstorm-related loss events with regard to climate change in Germany. Theoret Appl Climatol 114(3):715-724. https://doi.org/10.1007/ s00704-013-0843-y

Giuggiola A, Bugmann H, Zingg A, Dobbertin M, Rigling A (2013) Reduction of stand density increases drought resistance in xeric Scots pine forests. Forest Ecol Manag 310:827-835. https://doi.org/10.1016/j.foreco.2013.09.030

Grier CC, Running SW (1977) Leaf area of mature northwestern coniferous forests: Relation to site water balance. Ecology 58(4):893-899

Handa IT, Körner C, Hättenschwiler S (2006) Conifer stem growth at the altitudinal treeline in response to four years of $\mathrm{CO}_{2}$ enrichment. Global Change Biol 12:2417-2430

Hanewinkel M, Cullmann D, Michiels H-G, Kändler G (2014) Converting probabilistic tree species range shift projections into meaningful classes for management. J Environ Manage 134:153-165. https://doi.org/10.1016/j. jenvman.2014.01.010

Hansen J, Nagel J (2014) Waldwachstumskundliche Softwaresysteme auf Basis von TreeGrOSS - Anwendung und theoretische Grundlagen. Beiträge aus der NW-FVA, Band 11, Göttingen

Hanson PJ, Weltzin JF (2000) Drought disturbance from climate change: Response of United States forests. Sci Total Environ 262(3):205-220. https:// doi.org/10.1016/S0048-9697(00)00523-4

Hättenschwiler S, Miglietta F, Raschi A, Körner C (1997) Thirty years of in situ tree growth under elevated $\mathrm{CO}_{2}$ : a model for future forest responses? Global Change Biol 3:463-471

Hogg EHT, Bernier PY (2005) Climate change impacts on drought-prone forests in western Canada. Forest Chron 81(5):675-682

Hyvönen R, Agren Gl, Linder S, Persson T, Cotrufo MF, Ekblad A, Freeman M, Grelle A, Janssens IA, Jarvis PG, Kellomäki S, Lindroth A, Loustau D, Lundmark T, Norby RJ, Oren R, Pilegaard K, Ryan MG, Sigurdsson BD, Strömgren M, van Oijen M, Wallin G (2007) The likely impact of elevated [CO ], nitrogen deposition, increased temperature and management on carbon sequestration in temperate and boreal forest ecosystems: a literature review. New Phytologist 173(3):463-480 
IPCC (2013) In: Stocker TF, Qin D, Plattner G-K, Tignor M, Allen SK, Boschung J, Nauels A, Xia Y, Bex V, Midgley PM (eds) Climate change 2013: the physical science basis. Contribution of working group I to the fifth assessment report of the intergovernmental panel on climate change. Cambridge University Press, Cambridge and New York

Jactel H, Petit J, Desprez-Loustau M-L, Delzon S, Piou D, Battisti A, Koricheva J (2011) Drought effects on damage by forest insects and pathogens : a metaanalysis. Global Change Biol. https://doi.org/10.1111/j.1365-2486.2011.02512.x

Kahle H-P, Spiecker H, Unseld R, Pérez-Martínez P-J, Prietzel J, Mellert KH, Straussberger R, Rehfuess KE (2008a) Temporal trends and spatial patterns of height growth in relation to changes in air temperature and precipitation, and in relation to levels of foliar nitrogen and nitrogen deposition. In: Kahle H-P, Kellomäki S, Karjalainen T, Mellert KH, Schuck A, Prietzel J, Agren Gl, Rehfuess KE, Spiecker (eds) Causes and consequences of forest growth trends in Europe. European Forest Institute, Leiden, Boston, pp 127-168

Kahle HP, van Oijen M, Spiecker H, Agren Gl, Chertov G, Kellomäki S, Mellert KH, Pérez-Martínez P-J, Prietzel J, Straussberger R, Rehfuess KE, Unseld R (2008b) Analysis of the relative importance of nutrients, climatic factors, and CO2 as causes of observed changes in growth. In: Kahle H-P, Kellomäki S, Karjalainen T, Mellert KH, Schuck A, Prietzel J, Agren Gl, Rehfuess KE, Spiecker (eds) Causes and consequences of forest growth trends in Europe. European Forest Institute, Leiden, Boston, pp 217-234

Kandlikar M, Risbey J, Dessai S (2005) Representing and communicating deep uncertainty in climate-change assessments. CR Geoscience 337:443-455. https://doi.org/10.1016/j.crte.2004.10.010

Kätzel R, Höppner K (2011) Adaptation strategies in forest management under the conditions of climate change in Brandenburg. Folia Forest Polon 53(1):43-51

Keenan TF, Hollinger D, Bohrer G, Dragoni D, Munger JW, Schmid HP, Richardson AD (2013) Increase in forest water-use efficiency as atmospheric carbon dioxide concentrations rise. Nature. https://doi.org/10.1038/nature12291

Kint V, Aertsen W, Campioli M, Vansteenkiste D, Delcloo A, Muys B (2012) Radial growth change of temperate tree species in response to altered regional climate and air quality in the period 1901 - 2008. Clim Change 115:343-363. https://doi.org/10.1007/s10584-012-0465-x

Klos RJ, Wang GG, Bauerle WL, Rieck JR (2009) Drought impact on forest growth and mortality in the southeast USA : an analysis using Forest Health and Monitoring data. Ecol Appl 19(3):699-708

Knutti R, Sedláček J (2012) Robustness and uncertainties in the new CMIP5 climate model projections. Nat Clim Chang. https://doi.org/10.1038/nclimate1716

Kohnle U, Albrecht A, Lenk E, Ohnemus K, Yue C (2014) Growth trends driven by environmental factors extracted from long term experimental data in southwest Germany. Allg Forst Jagdztg 185(5-6):97-117

Kölling C, Bachmann M, Falk W, Grünert S, Schaller R, Tretter S (2009) KlimaRisikokarten für heute und morgen. AFZ-Der Wald 64:806-810

Körner C (2006) Plant $\mathrm{CO}_{2}$ responses: an issue of definition, time and resource supply. New Phytol 172(3):393-411. https://doi.org/10.1111/j. 1469-8137.2006.01886.x

Lappi J (1997) A longitudinal analysis of height/diameter curves. Forest Sci 43 555-570

Lindner M, Fitzgerald JB, Zimmermann NE, Reyer C, Delzon S, van der Maaten E, Schelhaas MJ, Lasch P, Eggers J, Van Der Maaten-Theunissen M, Suckow F, Psomas A, Poulter B, Hanewinkel M (2014) Climate change and European forests: what do we know, what are the uncertainties, and what are the implications for forest management? J Environ Manage 146:69-83. https:// doi.org/10.1016/j.jenvman.2014.07.030

Lindner M, Maroschek M, Netherer S, Kremer A, Barbati A, Garcia-Gonzalo J, Seidl R, Delzon S, Corona P, Kolström M, Lexer MJ, Marchetti M (2010) Climate change impacts, adaptive capacity, and vulnerability of European forest ecosystems. Forest Ecol Manage 259:698-709. https://doi.org/10.1016/j. foreco.2009.09.023

Menzel A (1997) Phänologie von Waldbäumen unter sich ändernden Klimabedingungen - Auswertung der Beobachtungen in den Internationalen Phänologischen Gärten und Möglichkeiten der Modellierung von Phänodaten. Dissertation, LMU, München

Michelot A, Breda N, Damesin C, Dufrene E (2012) Differing growth responses to climatic variations and soil water deficits of Fagus sylvatica, Quercus petraea and Pinus sylvestris in a temperate forest. Forest Ecol Manage 265:161-171. https://doi.org/10.1016/j.foreco.2011.10.024

Moss RH, Edmonds JA, Hibbard KA, Manning MR, Rose SK, Van Vuuren DP, Carter TR, Emori S, Kainuma M, Kram T, Meehl GA, Mitchell JFB, Nakicenovic N, Riahi K, Smith SJ, Stouffer RJ, Thomson AM, Weyant JP, Wilbanks TJ (2010) The next generation of scenarios for climate change research and assessment. Nature 463(7282):747-756. https://doi.org/10.1038/nature08823

Nagel J (2013) Waldwachstumssimulatoren und Forstliche Nachhaltigkeit. In: Klädtke U, Kohnle U (eds) Deutscher Verband Forstlicher Forschungsanstalten. Sektion Ertragskunde. Annual conference, Rychnov nad Kneznou, pp 122-126

Nagel J (2017) Dokumentation der neuen Ertragstafeln für Hochdurchforstung. Internal paper, NW-FVA, Göttingen

Näsholm T, Nohrstedt H-Ö, Karen O, Kytö M, Björkman C (2000) How are forest trees affected? In: Bertills U, Näsholm T (eds) Effects of nitrogen deposition on forest ecosystems. Swedish Environmental Protection Agency, Stockholm, pp 53-75

Ogden AE, Innes J (2007) Incorporating climate change adaptation considerations into forest management planning in the boreal forest. Intl Forest Rev 9(3):713-733

Orlowsky B, Gerstengarbe FW, Werner PC (2008) A resampling scheme for regional climate simulations and its performance compared to a dynamical RCM. Theoret Appl Climatol 92(3-4):209-223. https://doi.org/ 10.1007/s00704-007-0352-y

Orwig DA, Abrams MD (1997) Variation in Radial Growth Responses to Drought Among Species, Site, and Canopy Strata. Trees 11:474-484

Overbeck M, Schmidt M (2012) Modelling infestation risk of Norway spruce by Ips typographus (L.) in the Lower Saxon Harz Mountains (Germany). Forest Ecol Manage 266:115-125. https://doi.org/10.1016/j.foreco.2011.11.011

Persson $\mathrm{H}$, Ahlström K (2002) Fine-root response to nitrogen supply in nitrogen manipulated Norway spruce catchment areas. Forest Ecol Manage 168(1-3): 29-41. https://doi.org/10.1016/S0378-1127(01)00726-5

Piovesan G, Biondi F, Di Filippo A, Alessandrini A, Maugeri M (2008) Droughtdriven growth reduction in old beech (Fagus sylvatica L.) forests of the central Apennines, Italy. Global Change Biol 14(6):1265-1281. https://doi.org/ 10.1111/j.1365-2486.2008.01570.x

Pretzsch H, Biber P, Schütze G, Uhl E, Rötzer T (2014) Forest stand growth dynamics in Central Europe have accelerated since 1870. Nat Commun 5: 4967. https://doi.org/10.1038/ncomms5967

Pretzsch H, Schütze G, Uhl E (2013) Resistance of European tree species to drought stress in mixed versus pure forests: Evidence of stress release by inter-specific facilitation. Plant Biol 15(3):483-495. https://doi.org/10.1111/j. 1438-8677.2012.00670.x

Reyer C, Lasch-Born P, Suckow F, Gutsch M, Murawski A, Pilz T (2014) Projections of regional changes in forest net primary productivity for different tree species in Europe driven by climate change and carbon dioxide. Ann Forest Sci 71(2):211-225. https://doi.org/10.1007/s13595-013-0306-8

Schelhaas MJ, Nabuurs GJ, Hengeveld G, Reyer C, Hanewinkel M, Zimmermann NE, Cullmann D (2015) Alternative forest management strategies to account for climate change-induced productivity and species suitability changes in Europe. Region Environ Change 15(8):1581-1594. https://doi.org/10.1007/ s10113-015-0788-z

Schmidt M (2010) Ein standortsensitives, longitudinales Höhen-DurchmesserModell als Lösung für das Standort-Leistungs-Problem in Deutschland. In: Nagel J (ed) Deutscher Verband Forstlicher Forschungsanstalten. Sektion Ertragskunde. Annual conference, Körbecke, pp 131-152

Schmidt M, Hansen J (2007) Validierung der Durchmesserzuwachsprognose des Waldwachstumssimulators BWINPRO 7.0 für Fichte und Buche für den Bereich der alten Bundesländer. In: Nagel J (ed) Deutscher Verband Forstlicher Forschungsanstalten. Sektion Ertragskunde. Annual conference, Alsfeld, pp 164-179

Schoneberg S (2017) Ein klimasensitives, autoregressives Modell zur Beschreibung der Einzelbaum-Mortalität. Dissertation, Georg-August-Universität, Göttingen

Schulla J (2015) Model Description WaSIM completely revised version of 2012 with 2013 and 2015 extensions, Zürich

Schulla J, Jasper K (2007) Model description WaSIM-ETH. Institute for Atmospheric and Climate Science, Swiss Federal Institute of Technology, Zürich

Spellmann H, Ahrends B, Albert M, Andert S, Barkmann T, Böcher M, Breckling B, Christen O, Dvorak J, Eggers M, Fleck S, Fohrer N, Gauly M, Gerowitt B, Gieseke D, Grocholl J, Hakes W, Hammes V, Hartje V, Haunert G, Hoffmann M, Hufnagel J, Isselstein J, Kätzel R, Kayser M, Kehr I, Knauer H, Krott M, Lambertz C, Lange A, Langer G, Leefken G, Löffler S, Meesenburg H, Meißner R, Messal H, Meyer P, Möhring B, Möller K, Nagel J, Nuske RS, Oetzmann A, Ohrmann S, Cv R, Riediger J, Schmidt M, Schröder J, Schröder W, Siebert R, Spindelndreher D, Stahlmann H, Stöck L, Sutmöller J, Svoboda N, Tänzer D, Av T, Ulber B, Wegner K, Werner PC, Winter M, Wüstemann H, Zander P, 
Ziesche T (2017) Nachhaltiges Landmanagement im Norddeutschen Tiefland. Beiträge aus der NW-FVA, Band 18, Göttingen. https://doi.org/10.17875/ gup2018-1073

Spellmann H, Albert M, Schmidt M, Sutmöller J, Overbeck M (2011) Waldbauliche Anpassungsstrategien für veränderte Klimaverhältnisse. AFZ-DerWald 66(11):19-23

Spellmann H, Meesenburg H, Schmidt M, Nagel R-V, Sutmöller J, Albert M (2015) Klimaanpassung ist Vorsorge für den Wald. Strategien zur Stabilisierung der Wälder - ohne Aktionismus. proWald - Magazin des Dt. Forstvereins 11:4-10

Spellmann H, Sutmöller J, Meesenburg H (2007) Risikovorsorge im Zeichen des Klimawandels. AFZ-DerWald 23:1246-1249

Spittlehouse DL (2005) Integrating climate change adaptation into forest management. Forest Chron 81(5):691-695

Spittlehouse DL, Stewart RB (2003) Adaptation to climate change in forest management. BC J Ecosyst Manage 4(1):1-11

Sprauer S, Nagel J (2015) Aboveground productivity of pure and mixed Norway spruce and European beech stands. Eur J Forest Res 134:781-792. https://doi. org/10.1007/s10342-015-0889-8

Stevens B, Giorgetta M, Esch M, Mauritsen T, Crueger T, Rast S, Salzmann M, Schmidt H, Bader J, Block K, Brokopf R, Fast I, Kinne S, Kornblueh L, Lohmann U, Pincus R, Reichler T, Roeckner E (2013) Atmospheric component of the MPI-M earth system model: ECHAM6. J Adv Model Earth Syst 5(2):146-172. https://doi.org/10.1002/jame.20015

Sutmöller J, Meesenburg H, Evers J, Wagner M (2017) Auswirkung der Trockenheit 2015 auf den Bodenwasserhaushalt und das Baumwachstum von Waldstandorten in Nordwestdeutschland. In: Nordwestdeutsche Forstliche Versuchsanstalt (eds.) Waldböden: Schutz und Nutzung. Beiträge aus der NW-FVA, Band 17: 83-98

Thurm EA, Uhl E, Pretzsch H (2016) Mixture reduces climate sensitivity of Douglas-fir stem growth. Forest Ecol Manage 376:205-220. https://doi.org/10 1016/j.foreco.2016.06.020

Tognetti R, Cherubini P, Innes J (2000) Comparative stem-growth rates of Mediterranean trees under background and naturally enhanced ambient $\mathrm{CO}_{2}$ concentrations. New Phytol 146:59-74

van Vuuren DP, Edmonds J, Kainuma M, Riahi K, Thomson A, Hibbard K, Hurtt GC, Kram T, Krey V, Lamarque J-F, Masui T, Meinshausen M, Nakicenovic N, Smith SJ, Rose SK (2011) The representative concentration pathways: an overview. Clim Change 109(1):5. https://doi.org/10.1007/s10584-011-0148-z

Volodin EM, Dianskii NA, Gusev AV (2010) Simulating present-day climate with the INMCM4.0 coupled model of the atmospheric and oceanic general circulations. Atm Ocean Phys 46(4):414-431. https://doi.org/10.1134/ S000143381004002X

von Wilpert K (1990) Die Jahrringstruktur von Fichten in Abhängigkeit vom Bodenwasserhaushalt auf Pseudogley und Parabraunerde: ein Methodenkonzept zur Erfassung standortspezifischer Wasserstreßdisposition. Freiburger bodenkundliche Abhandlungen, Freiburg, p 24

Vospernik S, Monserud RA, Sterba H (2010) Do individual-tree growth models correctly represent height : diameter ratios of Norway spruce and Scots pine? Forest Ecol Manage 260(10):1735-1753. https://doi.org/10.1016/j.foreco. 2010.07.055

Vospernik S, Monserud RA, Sterba H (2015) Comparing individual-tree growth models using principles of stand growth for Norway spruce, Scots pine, and European beech. Can J Forest Res 45:1006-1018. https://doi.org/10.1139/cjfr2014-0394

Walker WE, Harresmoes P, Rotmans J, van der SJP, van Asselt MBA, Janssen P, Krayer von Krauss MP (2003) Defining Uncertainty - A Conceptual Basis for Uncertainty Management. Integr Assess 4(1):5-17

Walther A, Linderholm HW (2006) A comparison of growing season indices for the Greater Baltic Area. Intl J Biometeorol 51(2):107-118. https://doi.org/10. 1007/s00484-006-0048-5

Weber P, Bugmann H, Pluess AR, Walthert L, Rigling A (2013) Drought response and changing mean sensitivity of European beech close to the dry distribution limit. Trees 27:171-181. https://doi.org/10.1007/s00468012-0786-4

Wechsung F, Wechsung M (2014) Short Communication Dryer years and brighter sky - the predictable simulation outcomes for Germany's warmer climate from the weather resampling model STARS. Intl J Climatol. https://doi.org/10. 1002/joc.4220

Wechsung F, Wechsung M (2015) A methodological critique on using temperature-conditioned resampling for climate projections as in the paper of Gerstengarbe et al . (2013) winter storm- and summer thunderstorm- related loss events in Theoretical and Applied Climatology (TAC). Theoret Appl Climatol. https://doi.org/10.1007/s00704-015-1600-1

Zhao X, Corral-Rivas J, Zhang C, Temesgen H, von Gadow K (2014) Forest observational studies-an essential infrastructure for sustainable use of natural resources. For Ecosystems 1(8):1-10

Zingg A, Bürgi A (2008) Trockenperioden seit 1900 und Waldwachstum: eine Analyse langfristiger Datenreihen. Schweiz Z Forstwes 159(10):352-361. https://doi.org/10.3188/szf.2008.0352

\section{Submit your manuscript to a SpringerOpen ${ }^{\circ}$ journal and benefit from:}

- Convenient online submission

- Rigorous peer review

- Open access: articles freely available online

- High visibility within the field

- Retaining the copyright to your article

Submit your next manuscript at $\boldsymbol{\nabla}$ springeropen.com 